\title{
Effects of Cropping Systems and Agricultural Lime on Soil Properties and Nutrient Content of Sugarcane on Acidified Soils of Kisumu County, Kenya
}

\author{
Jacob Omondi Omollo, ${ }^{1, \text {, *, Ernest Semu }}{ }^{2}$, John Msaky², Philip Owuor ${ }^{3}$ \\ ${ }^{1}$ Kenya Agricultural and Livestock Research Organization, Sugar Research Institute, Kisumu, Kenya \\ ${ }^{2}$ Department of Soil and Geological Sciences, Sokoine University of Agriculture, Morogoro, Tanzania \\ ${ }^{3}$ Department of Chemistry, Maseno University, Kisumu, Kenya
}

\section{Email address:}

jac.omollo@gmail.com (J. O. Omollo)

${ }^{*}$ Corresponding author

\section{To cite this article:}

Jacob Omondi Omollo, Ernest Semu, John Msaky, Philip Owuor. Effects of Cropping Systems and Agricultural Lime on Soil Properties and Nutrient Content of Sugarcane on Acidified Soils of Kisumu County, Kenya. American Journal of Agriculture and Forestry.

Vol. 4, No. 4, 2016, pp. 97-111. doi: 10.11648/j.ajaf.20160404.14

Received: June 28, 2016; Accepted: July 7, 2016; Published: July 23, 2016

\begin{abstract}
Acid soils cause soil fertility problems such as $\mathrm{Al}$ and $\mathrm{Mn}$ toxicity, $\mathrm{Ca}, \mathrm{Mg}, \mathrm{N}$ deficiency and $\mathrm{P}$ fixation. These are constraints to high crop yields. Historically, liming is the common management practice used to neutralize soil acidity and to overcome the problems associated with soil acidification. A field experiment was conducted to investigate the effects of cropping systems, lime placement methods and lime rates on some soil chemical properties and nutrient uptake by sugarcane during the plant crop and ratoon one cycle under acidified Cambisols of Kibos, Kisumu, Kenya. A Split - split plot in randomized complete block arrangement was employed. The factors and respective levels (in parenthesis were): main plot; two cropping systems (sugarcane monoculture $[\mathrm{MC}]$ and intercropped sugarcane and soybeans $[\mathrm{IC}]$ ). The sub - plots were three lime placement methods (lime broadcasted [L-BC], lime shallow banded, $0-15 \mathrm{~cm}$ [L-SB] and lime deep banded, $15-30 \mathrm{~cm}$ (L-DB] and the sub - sub plots were three lime rates $\left(0,1\right.$ and $\left.2 \mathrm{t} \mathrm{ha}^{-1}\right)$. Lime rate of $2 \mathrm{t} \mathrm{ha}^{-1}$ significantly $(\mathrm{P} \leq 0.05)$ increased soil $\mathrm{pH}$ to 6.4 and 5.2 as determined in water and $1 \mathrm{~N} \mathrm{KCl}$, respectively compared to $1 \mathrm{tha}^{-1}$ and control $\left(0 \mathrm{tha}^{-1}\right)$. Increased lime rate led to decreased levels of manganese, iron, and copper hence confirms the inverse relationship between soil $\mathrm{pH}$ and these micronutrients. Lime deep banded (L-DB) increased soil pH and available phosphorus for soil depth $15-30 \mathrm{~cm}$ compared to lime shallow banded (L-SB) and lime broadcasted (L-BC). Intercropped sugarcane and soybeans (IC) led to increased soil acidity and soil organic carbon (SOC) than did sugarcane monoculture (MC). For nutrient content of sugarcane leaves, IC system led to increased $\mathrm{Ca}$ and $\mathrm{Mn}$ compared to MC. Lime broadcasted (L-BC) caused high nitrogen and phosphorus content of sugarcane leaves and lime shallow banded resulted in increased $\mathrm{Ca}$ and $\mathrm{Zn}$ content of sugarcane to optimum levels. In view of the findings, the lime rate of $2 \mathrm{tha}^{-1}$ is recommended for use to ameliorate soil acidity for acidified Cambisols of Kibos, Kisumu County, Kenya. Lime broadcasted (L-BC) is preferred to ameliorate acidity at top depth $(0-15$ $\mathrm{cm}$ ) while lime banded both (L-SB) and L-DB) is preferred to reduce sub - soil acidity.
\end{abstract}

Keywords: Soil pH, Lime Rates, Lime Placements, Cropping, Nutrient Content

\section{Introduction}

Acidified soils are a major constraint to crop production. In western Kenya, soil acidity is an economic and natural resource threat [1]. Soil acidity causes soil fertility problems such as Aluminium ( $\mathrm{Al}$ ) and Manganese (Mn) toxicity,
Calcium (Ca) and Magnesium (Mg) deficiency and low Molybdenum (Mo) and Phosphorus (P) availability [2, 3, 4]. [4] highlighted the detrimental effects of soil acidity to plants and soil organisms. Activities of soil organisms are reduced leading to the inhibition of biological nitrogen fixation (BNF) by legumes and decomposition of organic matter. Low $\mathrm{pH}$ may also result in the deficiency of $\mathrm{Ca}$ and $\mathrm{Mg}$ in 
soils [5]. Soil acidification is a natural process but it does also occur under managed ecosystems. [4] stated that regular fertilizer use is one of the major causes of soil acidification under managed ecosystems. Fertilizer - caused soil acidification occurs due to long term use of acidifying fertilizer such as urea and diammonium phosphate coupled with continuous monoculture.

Soil acidity affects availability of the macronutrients and micronutrients. Soils that are adequately limed are high in Ca. Very acid soils (soil pH less than 5.0) and soils that have received very excessive amounts of potassium and/or magnesium are conducive to $\mathrm{Ca}$ deficiency [6]. For $\mathrm{Mg}$, acid soils, especially sands, frequently contain low levels of $\mathrm{Mg}$. Soils of neutral or high $\mathrm{pH}$ usually contain adequate $\mathrm{Mg} . \mathrm{Mg}$ deficiency in soils arises when the lime materials used are low in $\mathrm{Mg}$, e.g. calcitic limestone. $\mathrm{Ca}$ and $\mathrm{Mg}$ deficiency, if it persists, leads to low yields since these nutrients play critical role in plant growth. $\mathrm{Ca}$ is a component of every cell wall and is involved in cell elongation and cell division. $\mathrm{Mg}$ is an essential part of chlorophyll molecule. It also activates many enzymes and aids in the formation of sugars, oils, and fats.

Soil $\mathrm{pH}$ is the most important factor influencing the availability of most micronutrients. As soil $\mathrm{pH}$ increases, the availability of iron $(\mathrm{Fe})$, manganese $(\mathrm{Mn})$, copper $(\mathrm{Cu})$ and zinc $(\mathrm{Zn})$ decreases. This is attributed to the cropping systems e.g. long term/ continual cropping have removed large amounts of the micronutrients, limited or lack of use of animal manure for crop production and use of high analysis fertilizers that lack micronutrients. As soil $\mathrm{pH}$ increases, the concentration of $\mathrm{Fe}$ in the soil solution decreases, with a minimum at $\mathrm{pH} 7.4$ to 8.5 . Mn availability to plants decreases as soil $\mathrm{pH}$ increases and may become deficient in soils with a $\mathrm{pH}$ above 6.5. Conversely, $\mathrm{Mn}$ availability increases as soil $\mathrm{pH}$ decreases and may become toxic in soils with $\mathrm{pH}$ below 5.5. The amount of soluble $\mathrm{Mn}$ increases 100 fold for each unit decrease in soil $\mathrm{pH}$, e.g. $\mathrm{pH} 5.0$ down to 4.0 [7].

Zinc availability to plants also decreases as soil $\mathrm{pH}$ increases and may become deficient in soils with a $\mathrm{pH}$ above 6.5 [7]. Liming soil to $\mathrm{pH}$ above 6.0 or 6.5 leads to reduction or elimination of $\mathrm{Zn}$ toxicity. The available $\mathrm{Cu}$ is held on the cation exchange complex in soils [8]. Increasing the soil $\mathrm{pH}$ by liming increases the amount of $\mathrm{Cu}$ held by clay and organic matter, decreasing $\mathrm{Cu}$ availability. Soils with a $\mathrm{pH}$ above 7.5 are more likely to be $\mathrm{Cu}$ deficient [4].

Liming is considered as a management practice to reduce the soil acidity [9]. Most plants grow well at a $\mathrm{pH}$ range of $5.5-6.5$ and liming is aimed to maintain the $\mathrm{pH}$ at this range. The benefits of liming include: enhanced soil physical, chemical and biological conditions. The indirect benefits include mobilization of plant nutrients, immobilization of toxic heavy metals, and improvements in soil structure. Liming also causes optimal conditions that enhance biological activities like $\mathrm{N}_{2}$ fixation and mineralization of $\mathrm{N}, \mathrm{P}$ and $\mathrm{S}$ in soils $[10,11]$.

In Kenya, the common sugarcane production practice is continuous sugarcane monoculture and use of acidifying fertilizers such as urea and diammonium phosphate [12]. These fertilizers are favoured due to their high levels of nutrient element per weight compared to other nutrient fertilizer sources. The advantage of these fertilizers means their use will be continued. This therefore calls for integrated use of these fertilizers with other soil improvement strategies that will mitigate against soil acidification, improve soil fertility and sugarcane nutrient uptake.

However, the cost of lime is prohibitive due to large amounts required. Alternative application strategies such as placement of lime in a band may allow lower rates of lime to be used and thereby offset economic constraints posed by high application rates. Liming, integrated with appropriate cropping systems may also lead to improved soil $\mathrm{pH}$ but also structure for sustained crop yields. Benefits of intercropping are: yield advantages of diverse crops, income, nutrition and also nitrogen $\left(\mathrm{N}_{2}\right)$ fixation which can cut costs on the use of $\mathrm{N}$ fertilizers. Farmers benefit from biological nitrogen fixation and therefore reduce soil $\mathrm{N}$ mining, which is estimated at $22 \mathrm{~kg} \mathrm{Nha}^{-1}$ for Sub Saharan Africa [13].

This study investigated whether lime use and intercropped sugarcane and soybeans leads to amelioration of soil $\mathrm{pH}$, soil nutrient status and nutrient content in sugarcane leaves. Also, the study determined the best lime rate, placement methods for improved soil $\mathrm{pH}$, soil fertility and sugarcane nutrition for plant crop and ratoon one crop cycle.

\section{Materials and Methods}

\subsection{Study Site}

The field experiment was conducted at field 6, experimental plots of Kibos $\left(35^{\circ} 13\right.$ E, $0^{\circ} 06$ S), KALRO Sugar Research Institute, Kisumu County, Kenya. The site elevation is $1268 \mathrm{~m}$ above sea level. The area is in agroecological zone (AEZ) LM 2, which is a marginal sugarcane zone and is sub humid. The soil type in field 6 is Eutric Cambisol [14] with the following soil properties: dark reddish brown friable sandy clay loam underlain by gravely red loam to light clay. The soil is well drained and has good physical properties and is slightly acid [15].

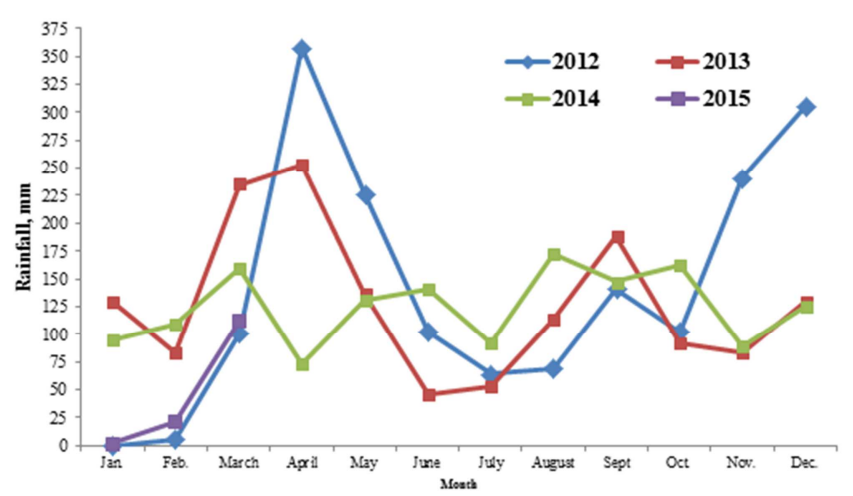

Figure 1. Precipitation data for the study site during the period of experiment (January 2012 to March 2015).

The weather data during the experiment period (2012 to 
2014) is shown in Figure 1, 2 and 3. The total annual rainfall was $1714 \mathrm{~mm}, 1544 \mathrm{~mm}$ and $1497 \mathrm{~mm}$ in 2012, 2013 and 2014, respectively (Figure 1).

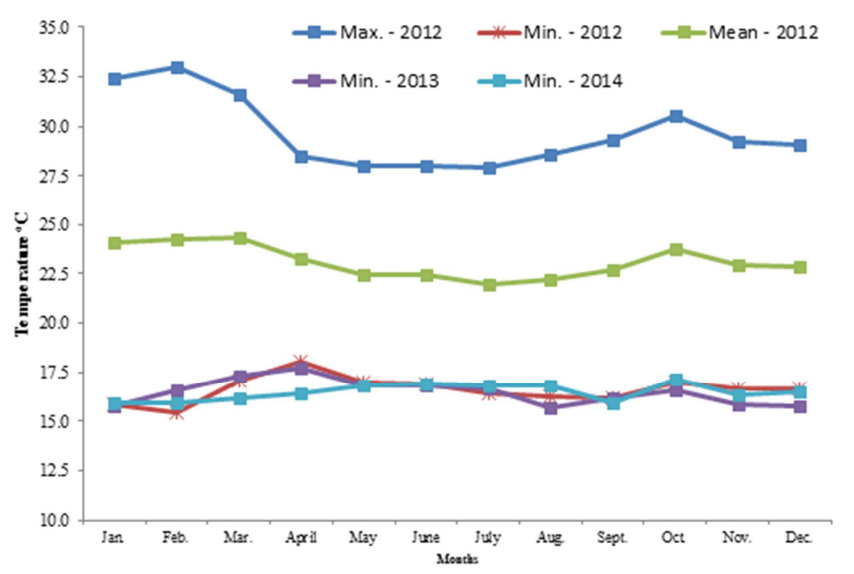

Figure 2. Temperature data for the study site during the period of experiment (2012 to 2014).

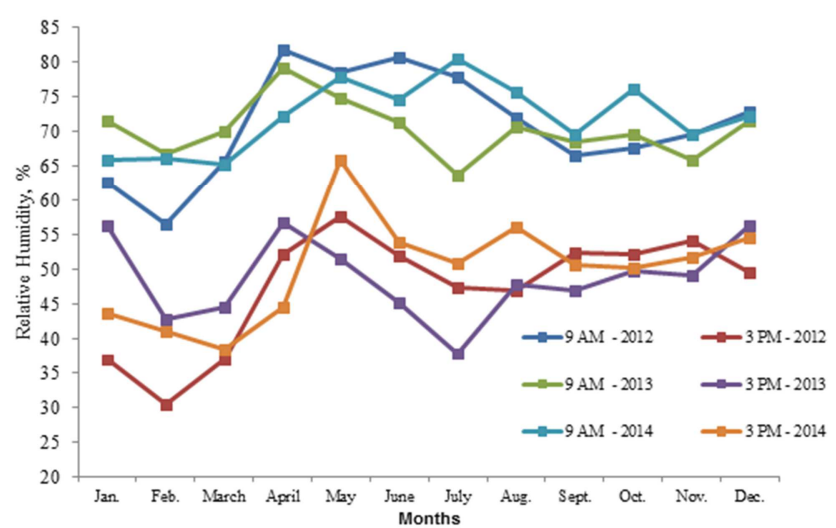

Figure 3. Relative humidity for the study site during the period of experiment (2012 to 2014).

The study area experiences bimodal rainfall characterized by two rainy seasons per year known as long and short rains. Long rains during 2012 to 2014 were from March to May while short rains were in September to October annually. This bimodal rainfall pattern reflects the pattern for the lake regions in Kenya [15]. Rainfall amounts are higher during long rains than short rain periods. The mean maximum temperature was $30^{\circ} \mathrm{C}$ while the minimum temperature ranged from $16^{\circ} \mathrm{C}$ to $17^{\circ} \mathrm{C}$ (Figure 2). The mean temperature was $23^{\circ} \mathrm{C}$. Relative humidity $(\% \mathrm{RH})$ was recorded at $9 \mathrm{AM}$ (0900 hours) and 3 PM (1500 hours) in 2012, 2013 and 2014 (Figure 3). Relative humidity at $9 \mathrm{AM}$ was higher than at 3 PM for all the years. Annual RH at 9 AM was $71 \%, 70 \%$ and $72 \%$ for 2012, 2013 and 2014, respectively, while it was $47 \%, 49 \%$ and $50 \%$ at $3 \mathrm{PM}$ for 2012, 2013 and 2014, respectively.

\subsection{Soil Chemical Properties Prior to Establishment of Field Experiment}

Soil testing for the study site was carried out prior to establishment of the field experiment. An area of about 0.5 ha was sampled. Diagonal sampling pattern was used and sampling points randomly selected. Soil auger was used to collect soil at depth $0-15 \mathrm{~cm}$ and also $15-30 \mathrm{~cm}$. The soil samples per depth across sampling points were composited and about a $\mathrm{kg}$ of soil was packaged in a well labelled brown paper bags. They were later dried, ground using pestle and mortar and sieved through a $2 \mathrm{~mm}$ sieve for chemical analysis. The soils were analysed for selected chemical properties using recommended methods as given in Table 1.

Generally, the magnitudes of the results for depth $0-15$ cm were higher as compared to depth $15-30 \mathrm{~cm}$ except extractable copper which showed the reverse. The ratings soil results were rated according to $[16,17]$ and [18]. For depth $0-15 \mathrm{~cm}$, the soil reaction was slightly acid (in water) and very strongly acid (in $\mathrm{KCl}$ ). For $15-30 \mathrm{~cm}$, soil reaction was medium acid (in water) and very strongly acid (in $\mathrm{KCl}$ ). Organic carbon was medium and low for $0-15 \mathrm{~cm}$ and $15-$ $30 \mathrm{~cm}$ respectively. Total nitrogen was low at both depths. Available $P$ was high at $0-15 \mathrm{~cm}$ and medium for $15-30$ $\mathrm{cm}$. The high $\mathrm{P}$ levels depicted residual $\mathrm{P}$ attributed to high and continual use of phosphorus fertilizer at planting, e.g. diammonium phosphate in the field for sugarcane production prior to establishment of field experiment. The micro elements copper, zinc, iron and manganese were sufficient, above the critical levels.

Table 1. Some chemical properties of the soils of the study site.

\begin{tabular}{|c|c|c|c|c|c|}
\hline Soil properties & Method of analysis & $0-15 \mathrm{~cm}$ depth & Rating & $15-30 \mathrm{~cm}$ depth & Rating \\
\hline $\mathrm{pH}\left(\mathrm{H}_{2} \mathrm{O}\right)$ & 1: 2.5 soil / water. Potentiometrically & 6.19 & Slightly acid & 5.93 & Medium acid \\
\hline $\mathrm{pH}(\mathrm{KCl})$ & 1: 2.5 soil / $1 \mathrm{~N} \mathrm{KCl}$. Potentiometrically & 5.04 & Very strongly acid & 4.73 & Very strongly acid \\
\hline Org. C (\%) & Dichromate Wet Oxidation & 1.30 & Medium & 1.23 & Low \\
\hline O. M (\%) & Convert using factor $1.72 \times$ Org, $\mathrm{C}$ & 2.24 & Medium & 2.11 & Medium \\
\hline Total N (\%) & Kjeldhal Method & 0.10 & Low & 0.1 & Low \\
\hline Avail. $\mathrm{P}\left(\mathrm{mg} \mathrm{kg}^{-1}\right)$ & Bray 1 & 20.52 & High & 11.91 & Medium \\
\hline Ex. $\mathrm{Cu} \mathrm{mg} \mathrm{kg}{ }^{-1}$ & Extracted using DTPA and measured using AAS & 1.53 & High & 1.60 & High \\
\hline Ex. $\mathrm{Zn} \mathrm{mg} \mathrm{kg}{ }^{-1}$ & DTPA & 1.79 & High & 1.52 & High \\
\hline Ex. Fe $\mathrm{mg} \mathrm{kg}^{-1}$ & DTPA & 147.9 & High & 137.2 & High \\
\hline Ex. Mn mg kg ${ }^{-1}$ & DTPA & 206.2 & High & 193.7 & High \\
\hline
\end{tabular}

DTPA - diethylenetriaminepenta acetic acid; AAS - Atomic absorption spectrophotometer. Ratings are according to [16, 17, 18]. Landon (1984), Estefan (2013), IUSS (2015) 


\subsection{Field Experiment}

The field experiment was established in 2012 and managed up to 2014. The field research period coincided with the sugarcane crop cycle, namely the plant crop $(0-18$ months after planting sugarcane setts) and the ratoon one crop cycle $(0-16$ months after ratoon emergence). Soybean was intercropped and managed during the stage when sugarcane was young (the period for sugarcane germination stage is usually between $0-60$ days after planting) and sugarcane tillering stage (this period is usually between $2^{\text {nd }}$ month and $7^{\text {th }}$ month after planting).

The experiment unit was a plot which measured [ $5 \mathrm{~m} \times 5$ rows each $1.2 \mathrm{~m}$ apart] referred to as gross plot. Data was collected in the net plots which are the three inner rows with the one row in each side referred to as guard rows. The sugarcane variety used was KEN $83-737$, which is of medium maturity at $0-18$ months and $0-16$ months for plant crop and ratoon crop cycle, respectively. Soybean variety SB 19 was used as intercrop which was sowed in between sugarcane rows. The soybean was inoculated with a rhizobial (Biofix ${ }^{\circledR}$ ) inoculant.

The experimental design for the field experiment was the split - split plot arranged in randomized complete blocks. The main plot was cropping system (CS) with two levels, namely sugarcane monoculture (MC) and intercropped sugarcane (IC). The sub - plots were lime placement methods (LPM) with three levels namely; lime broadcasted (L-BC), lime shallow banded (L-SB) at soil depth $0-15 \mathrm{~cm}$ and lime deep banded (L-DB) at soil depth $15-30 \mathrm{~cm}$. The sub - sub plots were lime rates with three levels namely 0,1 and 2 tonnes $\mathrm{ha}^{-1}$. This gave a total of 18 treatments which were then replicated three times to give a total of 54 plots. Agricultural lime $(20 \%$ $\mathrm{CaO}$ ) mined in Koru, Kisumu County, was used as the liming material. The raw limestone is carbonanite which is volcanic in origin. The lime treatments were applied prior to planting of sugarcane setts. Sugarcane setts were treated with imidacloprid (confidor $(\mathbb{R}$ ) at $200 \mathrm{~g} / \mathrm{L}$ to control termite attack. Termite mounds within the vicinity of the field experiment sites were identified and drenched with confidor. Similarly, the sugarcane planting furrows were drenched using confidor. After 30 to 45 days after planting sugarcane, germination of sugarcane was started. This time, soybean was sowed as intercrop, in between the sugarcane rows. Soybean was inoculated with rhizobial (biofix $\mathbb{R}$ ) inoculant. The sugarcane was managed for 18 months and harvested as the plant crop. It was also managed for the ratoon one crop for 16 months and harvested. Ratoon crop establishment involved alignment of the sugarcane trash in between sugarcane rows following green sugarcane harvest of plant crop cycle. Soybean intercrop was managed for 6 months and the pods harvested upon maturity. The above ground soybean biomass residue was then incorporated into the soil during manual weed control using a hoe. Soil sampling per plot was carried out after harvest of sugarcane plant crop and soon after trash alignment. Sugarcane leaf sampling for plant tissue tests was carried out at $18^{\text {th }}$ month of the plant crop cycle, and also during the ratoon crop cycle at $9^{\text {th }}$ and $12^{\text {th }}$ month after sugarcane ratoon emergence.

\subsection{Soil Analysis During the Field Experiment}

\subsubsection{Soil Sampling at Post-Harvest of Sugarcane}

Soil was sampled in each of the treatment plots. In every plot, a diagonal pattern was used to mark the sampling points. Soil auger was then used to collect soil sample at depth $0-15 \mathrm{~cm}$ (top soil) and $15-30 \mathrm{~cm}$ (sub soil). Soils sampled were then composited per depth for each treatment. About $0.5 \mathrm{~kg}$ of soil was then packed and the package well labelled.

\subsubsection{Soil Analysis}

Soil samples were air - dried, crushed using a mortar and pestle and sieved using a $2 \mathrm{~mm}$ sieve to remove debris. The parameters analysed were soil $\mathrm{pH}$, total nitrogen $(\mathrm{N})$, extractable phosphorus, organic carbon, exchangeable bases (sodium, calcium, magnesium and potassium), cation exchange capacity and also micro nutrients, i.e. manganese, iron, zinc and copper. Soil $\mathrm{pH}$ was determined in water and also $1 \mathrm{~N} \mathrm{KCl}$ at the ratio of 1 soil: 2.5 extractant. About $10 \mathrm{~g}$ of soil was transferred into $100 \mathrm{ml}$ plastic bottle followed by $25 \mathrm{ml}$ of the extractant. The mixture was shaken for 30 minutes, allowed to settle for 5 minutes and the supernatant solution read using an electrode $\mathrm{pH}$ meter $[19,20]$. Total $\mathrm{N}$ was determined by the Kjedahl method [21] whereby one gram of soil was put in a digestion tube, followed by addition of $10 \mathrm{ml} 98 \%$ $\mathrm{H}_{2} \mathrm{SO}_{4}$ and a scoop of mixed catalyst which contained 100 $\mathrm{g}$ potassium sulphate, $10 \mathrm{~g}$ copper sulphate and $1.55 \mathrm{~g}$ selenium powder. This mixture was then digested in a digestion block for 1 hour at $360^{\circ} \mathrm{C}$. The digest was then distilled after adding $40 \% \mathrm{NaOH}$, and the distillate collected over $4 \%$ boric acid, followed by titration with $0.05 \mathrm{~N} \mathrm{H}_{2} \mathrm{SO}_{4}$. The titre value was used to compute total $\mathrm{N}$. The Wakley - Black Method was used to determine soil organic carbon (OC) [20]. One gram of finely ground soil was put in a conical flask. Ten $\mathrm{ml}$ of $\mathrm{K}_{2} \mathrm{Cr}_{2} \mathrm{O}_{7}$ solution, 10 $\mathrm{ml}$ phosphoric acid $\left(85 \% \mathrm{H}_{3} \mathrm{PO}_{4}\right)$ solution and $20 \mathrm{ml}$ of $98 \% \mathrm{H}_{2} \mathrm{SO}_{4}$ were added. The mixture was swirled to mix, left for 30 minutes, cooled and then titrated. Diphylemine indicator was added and mixture titrated using ferrous sulfate. Organic carbon was then computed using amount of dichromate used in the oxidation.

Extractable $\mathrm{P}$ was determined using the Bray 1 method [20]. Five grams of soil was put in $50 \mathrm{ml}$ plastic bottle followed by $25 \mathrm{ml}$ of extraction solution. The mixture was hand shaken for one minute and then filtered. Five $\mathrm{ml}$ of the filtrate was then transferred into a $50 \mathrm{ml}$ volumetric flask. About $30 \mathrm{ml}$ distilled water was added followed by $10 \mathrm{ml}$ of the phospho - molybdate reagent. The mixture in the volumetric flask was then made to the mark using distilled 
water and was allowed to settle for about 30 minutes for colour development. The absorbance was measured by spectrophotometer at $884 \mathrm{~nm}$ wavelength [20].

Soil cation exchange capacity (CEC) and exchangeable bases were determined by ammonium acetate saturation at $\mathrm{pH} 7.0$ [20]. Five grams of soil was placed in $100 \mathrm{ml}$ plastic bottle followed by $35 \mathrm{ml}$ of $1 \mathrm{M}$ ammonium acetate buffered at $\mathrm{pH}$ 7. This mixture was shaken for half an hour and left overnight. The suspension was filtered into $100 \mathrm{ml}$ volumetric flask which was then used to determine exchangeable $\mathrm{Ca}, \mathrm{Mg}, \mathrm{K}$ and $\mathrm{Na}$. The remaining soil was washed with $80 \%$ ethanol and leached with $1 \mathrm{M} \mathrm{KCl}$ and then filled into $100 \mathrm{ml}$ volumetric flask. The leachate was transferred into a Kjeldtex distillation tube, $10 \mathrm{ml}$ of $40 \%$ $\mathrm{NaOH}$ added, the distillate collected over $4 \%$ boric acid and thereafter titred using $0.1 \mathrm{~N} \mathrm{H}_{2} \mathrm{SO}_{4}[20]$. The titre value from titration was used to calculate $\mathrm{CEC}$. The ammonium acetate leachate was used to determine exchangeable $\mathrm{Ca}$ and $\mathrm{Mg}$ using an atomic absorption spectrophotometer while for exchangeable $\mathrm{K}$ and $\mathrm{Na}$ the flame emission spectrophotometer was used.

Extractable $\mathrm{Fe}, \mathrm{Mn}, \mathrm{Zn}$ and $\mathrm{Cu}$ were determined after extraction using the DTPA - extractant. Fifteen grams of soil was placed in $100 \mathrm{ml}$ plastic bottles followed by addition of $40 \mathrm{ml}$ of DTPA. The mixture was then shaken for 2 hours and filtered into $50 \mathrm{ml}$ plastic bottles. The filtrate was used to determine $\mathrm{Fe}, \mathrm{Mn}, \mathrm{Zn}$ and $\mathrm{Cu}$ at respective wavelengths using an atomic absorption spectrophotometer [20].

\subsection{Plant Tissue Analysis}

As already mentioned sugarcane leaf was sampled at $18^{\text {th }}$ month of sugarcane age after planting for the plant crop cycle and also at $9^{\text {th }}$ and $12^{\text {th }}$ months of the ratoon one crop. The sampling unit was sugarcane stool. Four sugarcane shoot were randomly selected within the net plots and marked. Third dew lap leaf from the tip was chosen and cut using scateur. The leaves were then placed in brown bags and well labelled. The leaves sampled were then taken to the laboratory.

Preparation of the leaf samples

In the laboratory, the leaf samples were gently cleaned using distilled water and debris / dirt removed. Using a sharp knife, the leaf midrib was removed, leaving only the leaf sheath. This was then placed in brown bags which were then placed in the oven to dry at $72^{\circ} \mathrm{C}$ to constant weight. The dried leaf samples were ground to fine texture using a plant mill. The ground leaf samples were subjected to dry ashing and also wet digestion. For dry ashing, 0.5 grams of the leaf samples was weighed in crucibles. The crucibles were then placed in a muffle furnace and heated for 3 hours at $600^{\circ} \mathrm{C}$. Ten $\mathrm{ml}$ of $6 \mathrm{~N}$
$\mathrm{HCl}$ and $10 \mathrm{ml}$ of distilled water were added into the crucible to dissolve the ash, and the solution was filtered using Whatman number 42 filter paper. The amount of filtrate collected was then put into $25 \mathrm{ml}$ volumetric flask and then topped up to mark using distilled water. The extract following dry ashing was used for determining $\mathrm{Mn}, \mathrm{Fe}, \mathrm{Zn}$ and $\mathrm{Cu}$ using respective wavelengths in an atomic adsorption spectrophotometer (AAS). One $\mathrm{ml}$ of extract was diluted and used for determining $\mathrm{Ca}$ and $\mathrm{Mg}$ in AAS and for K using a flame photometer.

The amount of $\mathrm{P}$ in the extract was determined using the ascorbic acid molybdate blue method. Total $\mathrm{N}$ in the plant samples was determined by the Kjedahl method. One gram of the plant samples was put in digestion tube, followed by addition of $10 \mathrm{ml} 98 \% \mathrm{H}_{2} \mathrm{SO}_{4}$ and a scoop of mixed catalyst. This mixture was then digested in a digestion block for 1 hour and at $360^{\circ} \mathrm{C}$. The digest was then distilled after adding $25 \mathrm{ml}$ of $40 \% \mathrm{NaOH}$ followed by titration with $0.05 \mathrm{~N}$ $\mathrm{H}_{2} \mathrm{SO}_{4}$ and boric acid indicator. The titre value was used to compute total $\mathrm{N}$.

\subsection{Statistical Analysis}

Data on soil chemical properties, nutrient content of sugarcane leaves as affected by the treatments were subjected analysis of variance using the GENSTAT software [22]. A $2 \times 3 \times 3$ general treatment structure in randomized blocks was used to analyse the data. Main plot effects and respective interactions on treatments were also analysed [22]. Comparison of means test was carried out using the least significance difference (LSD) at the 5\% probability level.

\section{Results and Discussions}

\subsection{Effects of Cropping Systems, Lime Placement Methods and Lime Rates on Soil Chemical Properties}

\subsubsection{Effects of Lime Rates on Some Soil Chemical Properties}

Findings from this study shows that some soil chemical properties were significantly affected by cropping systems (CS), lime placement methods (LPM), lime rates (LR) and respective interactions as shown in Table 2, 3, 4, 5 and 6. Lime rates significantly affected the soil $\mathrm{pH}$ (in water and $\mathrm{KCl}$ ) for both $0-15 \mathrm{~cm}$ and $15-30 \mathrm{~cm}$ depth (Table 2 and 3). Plots limed at $2 \mathrm{t} \mathrm{ha}^{-1}$ recorded highest soil $\mathrm{pH}$ compared to plots limed at $1 \mathrm{t} \mathrm{ha}^{-1}$ and control plots (not limed, $0 \mathrm{t} \mathrm{ha}^{-1}$ ) (Table 3 ). Lime rates significantly affected soil extractable Mn for $0-15 \mathrm{~cm}$ soil depth (Table 4 and 5). Highest amount of extractable Mn was recorded in control (not limed plots) while lowest amount was recorded in plots limed at $1 \mathrm{t} \mathrm{ha}^{-1}$ and $2 \mathrm{t} \mathrm{ha}^{-1}$ (Table 5). 
Table 2. F-test probabilities of the effects of cropping systems (CS), lime placement methods (LPM) and lime rates on soil pH, organic carbon, total nitrogen and extractable phosphorus for $0-15 \mathrm{~cm}$ (top) and $15-30 \mathrm{~cm}$ (sub) soil depth.

\begin{tabular}{lllllllllll}
\hline \multirow{2}{*}{ F - Test probabilities } & \multicolumn{2}{l}{ Soil $\mathbf{p H}$ (in $\left.\mathbf{H}_{\mathbf{2}} \mathbf{O}\right)$} & \multicolumn{2}{l}{ Soil $\mathbf{p H}$ (in $\mathbf{K C l})$} & \multicolumn{2}{l}{ OC } & & \multicolumn{2}{c}{ Total N } & \multicolumn{2}{c}{ Extractable P } \\
\cline { 2 - 11 } & Top & Sub & Top & Sub & Top & Sub & Top & Sub & Top & Sub \\
\hline CS & NS & $<0.001$ & $<0.001$ & 0.003 & 0.026 & 0.008 & NS & NS & NS & NS \\
LPM & NS & $<0.001$ & NS & 0.003 & NS & 0.039 & NS & NS & 0.039 & 0.003 \\
LR & 0.013 & $<0.001$ & 0.004 & 0.002 & NS & NS & NS & NS & NS & NS \\
CS x LPM & NS & NS & $<0.001$ & NS & NS & 0.01 & NS & 0.013 & NS & 0.014 \\
CS x LR & NS & NS & NS & NS & 0.011 & Ns & NS & NS & NS & NS \\
LPM x LR & NS & NS & NS & 0.021 & NS & NS & NS & NS & NS & NS \\
CS x LP x LR & NS & NS & 0.002 & NS & NS & NS & NS & NS & NS & NS \\
CV (\%) & 3.2 & 2.7 & 4.5 & 5.2 & 21.3 & 21.1 & 13.4 & 12.9 & 35.7 & 26.8 \\
\hline
\end{tabular}

Significant effect at $\mathrm{P} \leq 0.05 ; \mathrm{CS}$ - cropping systems; LPM - lime placement methods; LR - lime rates; $\mathrm{OC}$ - organic carbon; $\mathrm{N}$ - nitrogen; $\mathrm{P}$ - phosphorus

Table 3. Effects of cropping systems (CS), lime placement methods (LPM) and lime rates (LR) on soil pH, organic carbon, total nitrogen and extractable phosphorus for $0-15 \mathrm{~cm}$ depth (top soil) and $15-30 \mathrm{~cm}$ depth (sub soil).

\begin{tabular}{|c|c|c|c|c|c|c|c|c|c|c|c|}
\hline \multirow[b]{2}{*}{ Factors } & \multirow[b]{2}{*}{ Levels } & \multicolumn{2}{|c|}{ Soil pH (in Water) } & \multicolumn{2}{|c|}{ Soil pH (in 1N KCl) } & \multicolumn{2}{|c|}{ OC $(\%)$} & \multicolumn{2}{|c|}{ total N (\%) } & \multicolumn{2}{|c|}{ Extractable $P(\mathrm{mg} / \mathrm{kg})$} \\
\hline & & Top & Sub & Top & Sub & Top & Sub & Top & Sub & Top & Sub \\
\hline \multirow[t]{3}{*}{ CS } & $\mathrm{MC}$ & 6.33 & $6.20 \mathrm{a}$ & $5.19 \mathrm{a}$ & $4.99 \mathrm{a}$ & $1.53 \mathrm{a}$ & $1.218 \mathrm{~b}$ & 0.10 & 0.102 & 20.30 & 12.48 \\
\hline & IC & 6.17 & $5.94 \mathrm{~b}$ & $4.95 \mathrm{~b}$ & $4.77 \mathrm{~b}$ & $1.75 b$ & $1.416 \mathrm{a}$ & 0.11 & 0.105 & 18.76 & 13.23 \\
\hline & $\operatorname{LSD}(\mathrm{P} \leq 0.05)$ & NS & 0.09 & 0.131 & 0.141 & 0.192 & 0.193 & NS & NS & NS & NS \\
\hline \multirow[t]{4}{*}{ LPM } & $\mathrm{L}-\mathrm{BC}$ & 6.21 & $5.94 \mathrm{c}$ & 5.02 & $4.74 \mathrm{~b}$ & 1.6 & $1.409 \mathrm{a}$ & 0.10 & 0.104 & $18.26 \mathrm{~b}$ & $14.3 \mathrm{a}$ \\
\hline & L-DB & 6.29 & $6.20 \mathrm{a}$ & 5.08 & $5.05 \mathrm{a}$ & 1.7 & $1.353 \mathrm{a}$ & 0.11 & 0.104 & $23.91 \mathrm{a}$ & $14.04 \mathrm{a}$ \\
\hline & L-SB & 6.25 & $6.07 \mathrm{~b}$ & 5.12 & $4.86 \mathrm{~b}$ & 1.6 & $1.189 \mathrm{~b}$ & 0.10 & 0.103 & $16.41 \mathrm{~b}$ & $10.22 \mathrm{~b}$ \\
\hline & $\operatorname{LSD}(\mathrm{P} \leq 0.05)$ & NS & 0.159 & NS & 0.172 & NS & 0.154 & NS & NS & 5.38 & 3.08 \\
\hline \multirow[t]{5}{*}{$\operatorname{LR}\left(\mathrm{t} \mathrm{ha}^{-1}\right)$} & 0 & $6.20 \mathrm{ab}$ & $5.93 \mathrm{c}$ & $5.04 \mathrm{~b}$ & $4.73 \mathrm{c}$ & 1.6 & 1.226 & 0.10 & 0.104 & 20.52 & 11.91 \\
\hline & 1 & $6.11 \mathrm{~b}$ & $6.07 \mathrm{~b}$ & $4.96 \mathrm{~b}$ & $4.85 \mathrm{~b}$ & 1.7 & 1.318 & 0.11 & 0.105 & 17.53 & 12.25 \\
\hline & 2 & $6.37 \mathrm{a}$ & $6.21 \mathrm{a}$ & $5.22 \mathrm{a}$ & $4.99 \mathrm{a}$ & 1.6 & 1.407 & 0.11 & 0.103 & 20.54 & 14.4 \\
\hline & $\operatorname{LSD}(\mathrm{P} \leq 0.05)$ & 0.137 & 0.091 & 0.156 & 0.118 & NS & NS & NS & NS & NS & NS \\
\hline & CV (\%) & 3.2 & 2.7 & 4.5 & 5.2 & 21.3 & 21.1 & 13.4 & 12.9 & 35.7 & 26.8 \\
\hline
\end{tabular}

Means in the same column followed by the same letter (s) are not significantly different at 0.05 level of significance Key: NS - not significant at $(\mathrm{P}=0.05)$; $\mathrm{CV}$ - coefficient of variation; MC - Sugarcane monoculture; IC - Intercropped sugarcane; L-BC - lime broadcasted; L-DB - lime deep banded; L-SB - lime shallow banded.

Table 4. F-test probabilities of the effects of cropping systems (CS), lime placement methods (LPM) and lime rates on soil extractable manganese, iron, zinc and copper for $0-15 \mathrm{~cm}$ and $15-30 \mathrm{~cm}$ soil depth.

\begin{tabular}{lllllllll}
\hline F - Test probabilities & \multicolumn{2}{l}{ Extractable Mn } & \multicolumn{2}{l}{ Extractable Fe } & \multicolumn{2}{l}{ Extractable Zn } & \multicolumn{2}{c}{ Extractable Cu } \\
\hline & Top & Sub & Top & Sub & Top & Sub & Top & Sub \\
\hline CS & 0.018 & $<0.001$ & 0.025 & 0.004 & NS & $<0.001$ & 0.026 & 0.008 \\
LPM & NS & NS & NS & 0.003 & NS & NS & NS & 0.039 \\
LR & 0.012 & NS & NS & NS & NS & NS & NS & NS \\
CS x LPM & NS & 0.049 & NS & 0.007 & NS & 0.041 & NS & 0.010 \\
CS x LR & NS & NS & NS & NS & NS & NS & 0.011 & NS \\
LPM x LR & NS & NS & NS & NS & NS & NS & NS & NS \\
CS x LPM x LR & NS & NS & NS & NS & NS & NS & NS & NS \\
CV (\%) & N & 9.9 & 20 & 18.5 & 13.4 & 11.7 & 10.4 & 11 \\
\hline
\end{tabular}

Significant effect at $\mathrm{P} \leq 0.05 ; \mathrm{CS}$ - cropping systems; LPM - lime placement methods; LR - lime rates; Mn - Manganese; Fe - Iron; $\mathrm{Zn}-\mathrm{Zinc}$; $\mathrm{Cu}$ - Copper 
Table 5. Effects of cropping systems (CS), lime placement methods (LPM) and lime rates (LR) on soil extractable manganese (Mn), iron (Fe), zinc (Zn) and copper (Cu) for $0-15 \mathrm{~cm}$ depth (top soil) and $15-30 \mathrm{~cm}$ depth (sub soil).

\begin{tabular}{|c|c|c|c|c|c|c|c|c|c|}
\hline \multirow[b]{2}{*}{ Factors } & \multirow[b]{2}{*}{ Levels } & \multicolumn{2}{|c|}{ Extractable Mn } & \multicolumn{2}{|c|}{ Extractable Fe } & \multicolumn{2}{|c|}{ Extractable Zn } & \multicolumn{2}{|c|}{ Extractable $\mathbf{C u}$} \\
\hline & & Top & Sub & Top & Sub & Top & Sub & Top & Sub \\
\hline \multirow[t]{3}{*}{$\mathrm{CS}$} & $\mathrm{MC}$ & $172.6 \mathrm{~b}$ & $171.2 \mathrm{~b}$ & $121.7 \mathrm{~b}$ & $121.7 \mathrm{~b}$ & 1.72 & $1.43 \mathrm{~b}$ & $1.53 b$ & $1.22 \mathrm{~b}$ \\
\hline & IC & $196.5 \mathrm{a}$ & $200.4 \mathrm{a}$ & $142.5 \mathrm{a}$ & $137.7 \mathrm{a}$ & 1.82 & $1.62 \mathrm{a}$ & $1.75 \mathrm{a}$ & $1.42 \mathrm{a}$ \\
\hline & $\operatorname{LSD}(P \leq 0.05)$ & 17.9 & 12.5 & 19.9 & 13.18 & NS & 0.114 & 0.192 & 0.142 \\
\hline \multirow[t]{4}{*}{ LPM } & L-BC & 185.1 & $195.5 \mathrm{a}$ & 137.30 & $145.3 \mathrm{a}$ & 1.73 & 1.552 & 1.60 & $1.41 \mathrm{a}$ \\
\hline & L-DB & 175.2 & $177.8 \mathrm{~b}$ & 134.50 & $112.3 b$ & 1.873 & 1.497 & 1.67 & $1.36 \mathrm{ab}$ \\
\hline & L-SB & 193.4 & $184.0 \mathrm{ab}$ & 124.5 & $125.0 \mathrm{~b}$ & 1.694 & 1.519 & 1.64 & $1.19 \mathrm{~b}$ \\
\hline & $\operatorname{LSD}(\mathrm{P} \leq 0.05)$ & NS & 15.4 & NS & 18.8 & NS & NS & NS & 0.107 \\
\hline \multirow[t]{5}{*}{ LR $\left(\mathrm{t} \mathrm{ha}^{-1}\right)$} & 0 & $203.2 \mathrm{a}$ & 193.7 & $147.9 \mathrm{a}$ & 137.2 & 1.796 & 1.524 & 1.61 & 1.602 \\
\hline & 1 & $175.4 \mathrm{~b}$ & 188.0 & $118.4 \mathrm{~b}$ & 126.8 & 1.729 & 1.509 & 1.67 & 1.634 \\
\hline & 2 & $172.1 \mathrm{~b}$ & 185.2 & $129.9 \mathrm{ab}$ & 125.0 & 1.773 & 1.535 & 1.63 & 1.57 \\
\hline & $\operatorname{LSD}(P \leq 0.05)$ & 21.9 & NS & 18.22 & NS & NS & NS & NS & NS \\
\hline & CV (\%) & 17.6 & 12.2 & 24 & 21.9 & 16.3 & 15.1 & 21.3 & 18.9 \\
\hline
\end{tabular}

Means in the same column followed by the same letter (s) are not significantly different at 0.05 level of significance. Key: NS - not significant at $(\mathrm{P}=0.05)$; $\mathrm{CV}$ - coefficient of variation; MC - Sugarcane monoculture; IC - Intercropped sugarcane; L-BC - lime broadcasted; L-DB - lime deep banded; L-SB - lime shallow banded.

The amounts of exchangeable $\mathrm{Ca}$ at both $0-15$ and $15-30 \mathrm{~cm}$ increased with increase in lime rates. Lime rate, $2 \mathrm{t}^{-1} \mathrm{gave}^{-1}$ the highest exchangeable $\mathrm{Ca}$ at both depths while the least was where there was no lime (Table 7).

Table 6. F- test probabilities for the effects of CS, LPM and LR on exchangeable bases for $0-15$ and $15-30 \mathrm{~cm}$ depth.

\begin{tabular}{lllllllll}
\hline F - test probabilities & \multicolumn{2}{l}{ Top, $\mathbf{0}-\mathbf{1 5} \mathbf{~ c m}$} & \multicolumn{5}{l}{ Sub, 15-30 cm } \\
\hline Treatments & Mg & Ca & K & Na & Mg & Ca & K & Na \\
\hline CS & 0.146 & 0.633 & 0.415 & 0.102 & 0.750 & 0.599 & 0.674 & 0.137 \\
LPM & 0.324 & 0.866 & 0.633 & 0.184 & 0.195 & 0.106 & 0.850 & 0.448 \\
LR & 0.192 & 0.004 & 0.872 & 0.059 & 0.200 & 0.015 & 0.328 & 0.550 \\
CS x LPM & 0.032 & 0.846 & 0.794 & 0.161 & 0.885 & 0.915 & 0.100 & 0.142 \\
CS x LR & 0.846 & 0.324 & 0.132 & 0.985 & 0.374 & 0.687 & 0.467 & 0.749 \\
LPM x LR & 0.121 & 0.142 & 0.092 & 0.269 & 0.434 & $<0.001$ & 0.589 & 0.793 \\
CS x LPM x LR & 0.276 & 0.790 & 0.835 & 0.125 & 0.284 & 0.215 & 0.463 & 0.508 \\
\hline
\end{tabular}

Significant effect at $\mathrm{P} \leq 0.05 ; \mathrm{CS}$ - cropping systems; LPM - lime placement methods;

Lime rate $2 \mathrm{tha}^{-1}$ led to highest soil $\mathrm{pH}$ and exchangeable Ca but lowest extractable Mn (Table 6 and 7 ).

Table 7. Effects of lime rates on exchangeable calcium.

\begin{tabular}{lll}
\hline & $\mathbf{0}-\mathbf{1 5} \mathbf{~ c m}$ soil depth & $\mathbf{1 5}-\mathbf{3 0}$ cm soil depth \\
\hline Lime rates, $\mathbf{t} /$ ha & Exc. Ca., cmol (+) / kg soil & Exc. Ca., cmol (+) / kg soil \\
\hline 0 & $19.37 \mathrm{~b}$ & $20.38 \mathrm{~b}$ \\
1 & $20.49 \mathrm{~b}$ & $22.63 \mathrm{a}$ \\
2 & $23.92 \mathrm{a}$ & $23.65 \mathrm{a}$ \\
LSD $(\mathrm{P} \leq 0.05)$ & 2.69 & 2.09 \\
CV\% & 18.7 & 13.9 \\
\hline
\end{tabular}

Means in the same column followed by the same letter (s) are not significantly different at 0.05 level of significance. Key: Exc. - exchangeable, Ca - calcium, $\mathrm{CV}$ - coefficient of variation

Several studies in Kenya reported that agricultural lime $(21 \% \mathrm{CaO})$ led to increased soil $\mathrm{pH}$ and exchangeable $\mathrm{Ca}$ [23, 24 and 25]. [4] stated that liming enhances the chemical, physical and biological characteristics of soil. Hence the chemical characteristics, soil $\mathrm{pH}$ and exchangeable $\mathrm{Ca}$ of the study site were enhanced. Lime reaction in acidic soil is that, lime dissolves in the soil then Ca moves to the surface of the soil particles (exchange sites) replacing the acidity. The 
acidity reacts with the carbonate $\left(\mathrm{CO}_{3}\right)$ to form carbon dioxide $\left(\mathrm{CO}_{2}\right)$ and water $\left(\mathrm{H}_{2} \mathrm{O}\right)$. The result is a soil with higher $\mathrm{pH}$ or less acidic and more exchangeable $\mathrm{Ca}$ [26].

The primary purpose of liming acid soils is to overcome the chemical problems associated with acidity for example high Mn level [4]. Liming acid soil is suggested as the best method to attain and maintain a suitable $\mathrm{pH}$ for the growth of a variety of crops Benefits of liming include improved nitrogen fixation and availability of essential nutrients (Ca, P, $\mathrm{Mo}$ ) and decreasing the solubility of toxic elements $\mathrm{Al}$ and Mn [10].

Other soil chemical properties that were not significantly affected by liming in this study were total $\mathrm{N}$, soil extractable $\mathrm{P}$, soil extractable $\mathrm{Mg}$, soil extractable $\mathrm{K}$, and soil extractable $\mathrm{Na}$, soil extractable $\mathrm{Fe}, \mathrm{Zn}$ and $\mathrm{Cu}$. The results are contrary to study by [4] who found out that increased liming causes increased mineralization / nitrification. It is therefore expected that plots that received lime should have indicated increased soil total N. Liming has often been shown to enhance the mineralization of organic matter, thereby releasing inorganic plant nutrients such as $\mathrm{N}, \mathrm{S}$ and $\mathrm{P}$ to soil solution. Unless these nutrients are actively taken up plants they are liable for leaching losses. The possible lack of significant difference may have been a result of the leaching of the soil nitrates [4]. Lime rates did not significantly affect soil extractable P (Table 2 and 3 ). The reason could be the adequate level of available $\mathrm{P}$ in the soil prior to establishment of the experiment (Table 1).

\subsubsection{Effects of Lime Placement Methods on Soil Chemical Properties for 0-15 cm and $15-30 \mathrm{~cm}$ Depth}

Lime placement methods significantly affected soil $\mathrm{pH}$ (in water), soil $\mathrm{pH}(1 \mathrm{~N} \mathrm{KCl})$, soil $\mathrm{OC}$, exchangeable $\mathrm{Ca}$, extractable $\mathrm{Fe}$ and $\mathrm{Cu}$ for $15-30 \mathrm{~cm}$ depth (Table 2, 4 and 6). Lime placement methods also affected soil extractable $P$ for $0-15 \mathrm{~cm}$ and $15-30 \mathrm{~cm}$ (Table 2). Plots that were deep banded with lime (LDB) recorded highest soil $\mathrm{pH}$, exchangeable $\mathrm{Ca}$ and extractable $\mathrm{P}$ for $15-30 \mathrm{~cm}$ depth (Table 3). Plots broadcasted banded with lime (LBC) recorded the highest soil $\mathrm{OC}$, extractable $\mathrm{Fe}$ and $\mathrm{Cu}$ for 15 $30 \mathrm{~cm}$. Lime deep banded (L-DB) plots showed highest exchangeable $\mathrm{Ca}$, while the least was in plots which were lime broadcasted (L-BC) as given in Table 8 .

Table 8. Effects of lime placement methods on exchangeable calcium.

\begin{tabular}{ll}
\hline & $\mathbf{1 5}$ - $\mathbf{3 0}$ cm soil depth \\
\hline Lime placement methods & Exc. Ca., cmol (+) / kg soil \\
\hline Lime broadcasted (L-BC) & $20.87 \mathrm{~b}$ \\
Lime shallow banded (L-SB) & $21.88 \mathrm{ab}$ \\
Lime deep banded (L-DB) & $23.91 \mathrm{a}$ \\
LSD (P $\leq 0.05)$ & 2.09 \\
CV\% & 13.9 \\
\hline
\end{tabular}

Means in the same column followed by the same letter (s) are not significantly different at 0.05 level of significance. Key: Exc. exchangeable, $\mathrm{Ca}$ - calcium, $\mathrm{CV}$ - coefficient of variation
Similar results of lime placement were reported on lime management in soybean no - tillage system in Brazil [27]. [27] worked with lime application using implements e.g. intermediate disk harrow and chisel plough. [27] noted that deeper incorporation raises the $\mathrm{pH}$ value to acceptable levels for improved yields. The results of this study are in agreement to those of [27] who concluded that lime incorporated with disc harrow and also lime incorporated with chisel plough resulted in improved chemical condition which then led to higher soybean yields. [27] noted that lime applied on the surface (broadcasted) increased exchangeable $\mathrm{Ca}$ and $\mathrm{Mg}$ until $0-15 \mathrm{~cm}$ depth. While lime incorporated in $0-20 \mathrm{~cm}$ depth led to increased $\mathrm{Ca}$ and $\mathrm{Mg}$ until $30 \mathrm{~cm}$ depth.

\subsubsection{Effects of Cropping Systems on Soil Chemical Properties for 0-15 cm and $15-30 \mathrm{~cm}$ Depth}

Cropping systems (CS) significantly affected the soil $\mathrm{pH}$, soil $\mathrm{OC}$, extractable $\mathrm{Mn}, \mathrm{Fe}$ and $\mathrm{Cu}$ for $0-15 \mathrm{~cm}$ and $15-30 \mathrm{~cm}$ (Table 2 and 4). Cropping systems affected extractable $\mathrm{Zn}$ for 15 - $30 \mathrm{~cm}$ depth. Plots under sugarcane monocrop recorded highest soil $\mathrm{pH}$ and also soil $\mathrm{OC}$ for $0-15 \mathrm{~cm}$ compared to plots under intercropped sugarcane and soybeans (Table 3 ). Plots under intercropped sugarcane and soybean recorded highest soil extractable $\mathrm{Mn}, \mathrm{Fe}, \mathrm{Cu}$ for both $0-15 \mathrm{~cm}$ and $15-$ $30 \mathrm{~cm}$. For $15-30 \mathrm{~cm}$, extractable $\mathrm{Zn}$ was recorded in plots intercropped with sugarcane and soybeans (Table 5).

The low $\mathrm{pH}$ under IC than $\mathrm{MC}$ is related to the decomposition of the soybean residues which were incorporated. According to [11] nodulated legumes acquire their $\mathrm{N}$ from the air as diatomic $\mathrm{N}$ rather than from the soil as nitrate which then leads to a net effect of lowered soil $\mathrm{pH}$. Decomposition of organic matter and transformation of $\mathrm{N}$ are some of the soil induced processes amongst others that contribute to acid generation in soils [4]. Decomposing plant litter rich in organic compounds but low in basic cations lead to production of organic acids by soil microorganism [28]. Soybeans residues are rich in organic compounds hence explain the possible reason for low soil $\mathrm{pH}$ under IC than MC system.

The high soil extractable $\mathrm{Mn}, \mathrm{Fe}, \mathrm{Zn}$ and $\mathrm{Cu}$ under IC is linked to the low $\mathrm{pH}$ recorded under IC system. These micronutrients tend to available under acid conditions. Generally, the solubility and phyto - availability of metals are inversely related to soil $\mathrm{pH}$. Several studies reported increased levels of soluble $\mathrm{Mn}$ with decrease in soil $\mathrm{pH}$ [5, 29]. [4] stated that Zinc ( $\mathrm{Zn}$ ) activity increases rapidly with decreasing $\mathrm{pH}$. The $\mathrm{pH}$-dependent solubility of $\mathrm{Zn}$ in soils is governed by a complex mixture of mechanisms including adsorption on sesquioxides, co - precipitation with $\mathrm{Al}$, and complexation with organic matter [30].

\subsection{Interaction Effects of Cropping Systems, Lime Placement Methods and Lime Rates on Some Soil Chemical Properties}

\subsubsection{Effects of CS x LPM on Soil pH (in $1 \mathrm{~N} \mathrm{KCl)} \mathrm{for} 0$ - $15 \mathrm{~cm}$ Soil Depth}

There was a significant $(\mathrm{P}<0.001)$ interaction effect between cropping systems and lime placement method on 
soil pH (Table 2 and Figure 4). This result indicates that the change in soil $\mathrm{pH}$ with regard to type cropping system and lime placement methods varies at different magnitude. The findings imply that, use of one lime placement method to a given cropping system will not show similar result to a different cropping system. Therefore each cropping system should have a respective lime placement method.

\subsubsection{Effects of CS $x$ LPM on Soil OC and Total N for 15 - $30 \mathrm{~cm}$ Soil Depth}

There was a significant interaction effect between cropping systems and lime placement method on soil OC and total $\mathrm{N}$ at $(\mathrm{P}=0.01)$ and $(\mathrm{P}=0.013)$ respectively (Table 2 and Figure 5). This result shows that variation in soil OC and total $\mathrm{N}$ as influenced by cropping system type and lime placement method differs based on the combination. Under IC plots, soil $\mathrm{N}$ increased in the following pattern, LSB > LDB > LBC. While under MC plots, soil $\mathrm{N}$ and soil $\mathrm{OC}$ decreased in the following pattern, LBC $<$ LDB $<$ LSB (Figure 5). The findings signify that a given lime placement method to a given cropping system will not show similar result to a different cropping system. Therefore each cropping system should have varied suitable lime placement method so as to benefit on soil OC and total $\mathrm{N}$

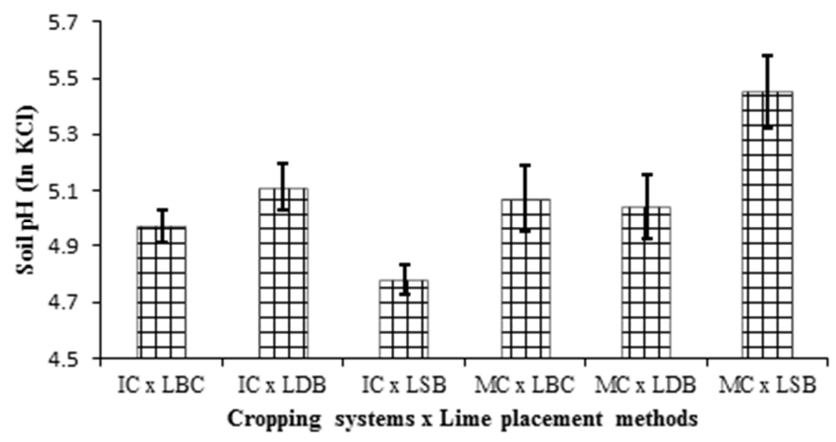

Figure 4. Interaction CS $x$ LPM on soil pH for $0-15 \mathrm{~cm}$ depth.

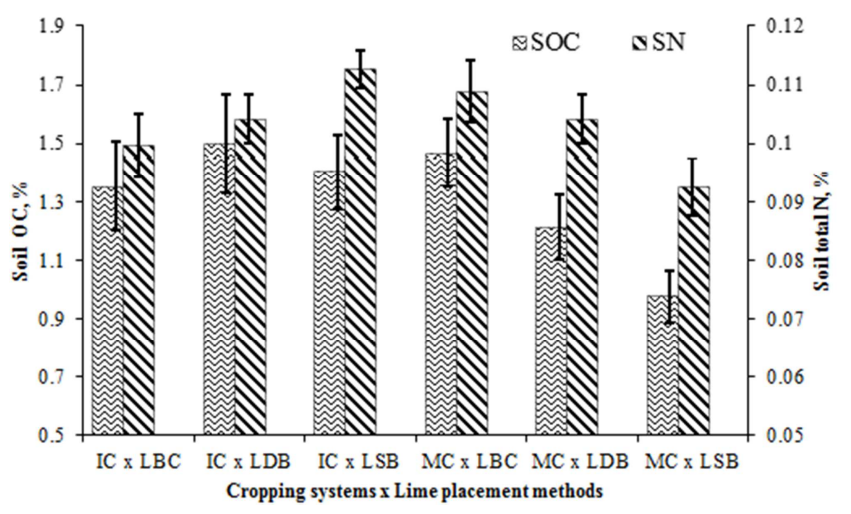

Figure 5. Interaction CS $x$ LPM on soil $O C$ and total $N$ for $15-30 \mathrm{~cm}$ depth.

\subsubsection{Effects of CS x LPM on Soil Exchangeable Mg for 0 - 15 cm Soil Depth}

There was a significant $(\mathrm{P}=0.032)$ interaction effect between cropping systems and lime placement method on soil extractable Mg (Table 6 and Figure 6). The CS x LPM indicated that, the change in soil exchangeable $\mathrm{Mg}$ based on the cropping system and the lime placement methods do no vary at the same magnitude. The results imply that it is important to consider lime placement methods for either sugarcane monocrop or intercropped sugarcane and soybeans.

\subsubsection{Effects of CS x LPM on Soil Extractable Manganese for $15-30 \mathrm{~cm}$ Depth}

There was a significant $(\mathrm{P}=0.007)$ interaction effect between cropping systems and lime placement methods on soil extractable Mn (Table 4 and Figure 7). Under MC system, amount of Mn decreased in the following pattern of lime placement method, LSB $<\mathrm{LDB}<\mathrm{LBC}$.

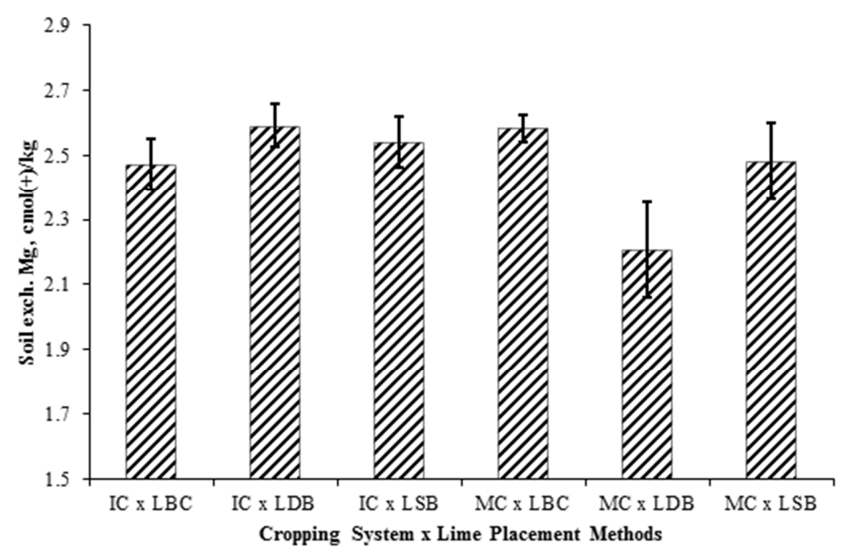

Figure 6. Interaction CS x LPM on soil exchangeable $M g$ for $0-15 \mathrm{~cm}$ depth.

This unlike under IC where soil Mn amount declined in plots broadcasted with lime (LBC) to plots LDB and then rose in plots LSB (Figure 7). Cropping systems (CS) influenced much on the soil $\mathrm{Mn}$ in the interaction. Therefore difference LPM should be used for each of the CS.

\subsubsection{Effects of CS x LR on Soil OC for 0-15 cm Depth}

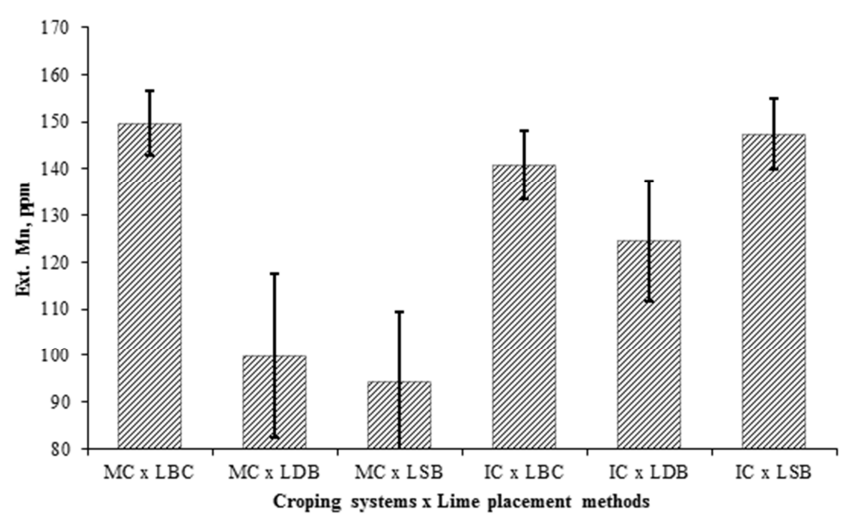

Figure 7. Interaction CS x LPM effect on soil extractable Mn for $15-30 \mathrm{~cm}$ depth.

There was a significant $(\mathrm{P}=0.01)$ interaction effect between cropping systems and lime rates on soil OC for $0-$ $15 \mathrm{~cm}$ depth (Table 2 and Figure 8). This result indicates that difference in soil OC as affected by CS and LR differs based 
on the interaction. Under $\mathrm{MC}$, soil $\mathrm{OC}$ decreased with increase in lime rates. While under IC, soil OC increased with increase in lime rates (Figure 8). This shows that in each cropping system, different lime rates should be used because the reaction of the lime rates varies.

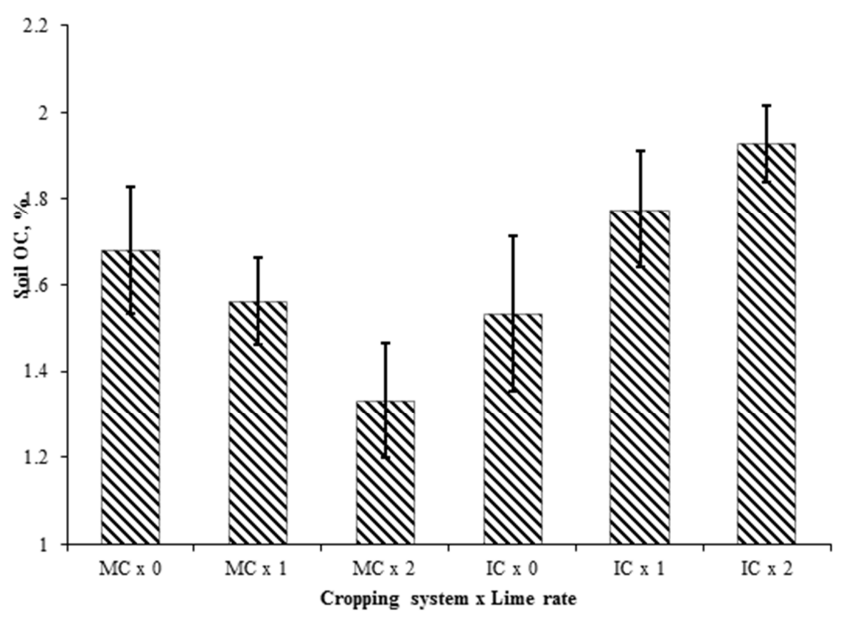

Figure 8. Effects of CS $x$ LR on soil OC for $0-15 \mathrm{~cm}$ depth.

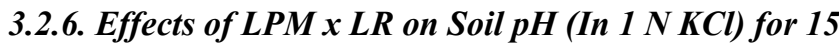 $-30 \mathrm{~cm}$}

There was a significant $(\mathrm{P}=0.021)$ interaction effect between lime placement methods and lime rates on soil $\mathrm{pH}$ (in $\mathrm{KCl}$ ) for $15-30 \mathrm{~cm}$ depth (Table 2 and Figure 9). There was increase in soil $\mathrm{pH}$ with increased lime where lime was banded deep and also shallow (Figure 9).

\subsubsection{Effects of LPM $x$ LR on Soil Exchangeable Ca for 15 $-30 \mathrm{~cm}$ Depth}

There was a significant $(\mathrm{P}<0.001)$ interaction effect between LMP and LR on exchangeable Ca (Table 6). Plots that had the combination LDB $\times 2 \mathrm{tha}^{-1}$ showed the highest $\mathrm{Ca}$ (Figure 10). This indicates that variation in soil exchangeable $\mathrm{Ca}$ is affected by varied LMP and also varied LR. Therefore, different lime rates should be determined for different LPM.

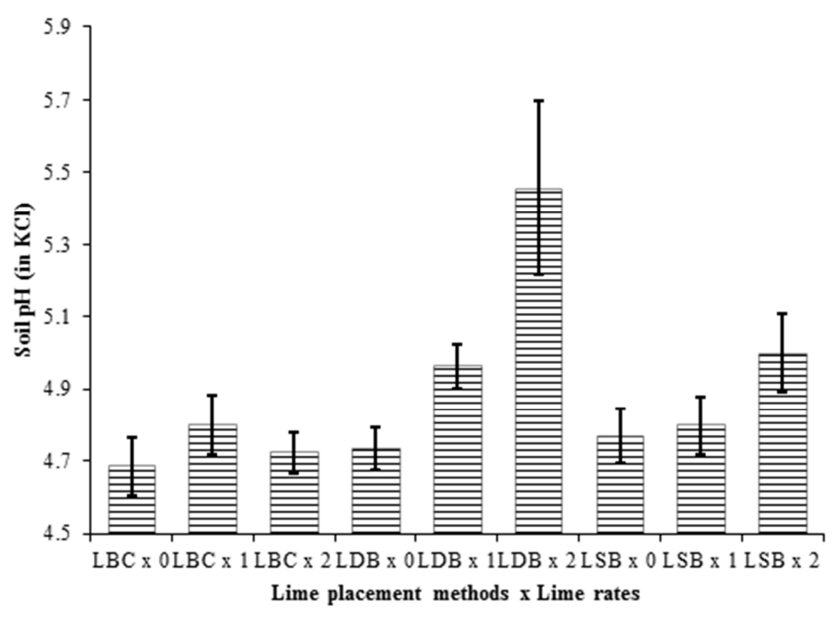

Figure 9. Effects of LPM $x$ LR on soil pH for $15-30 \mathrm{~cm}$.

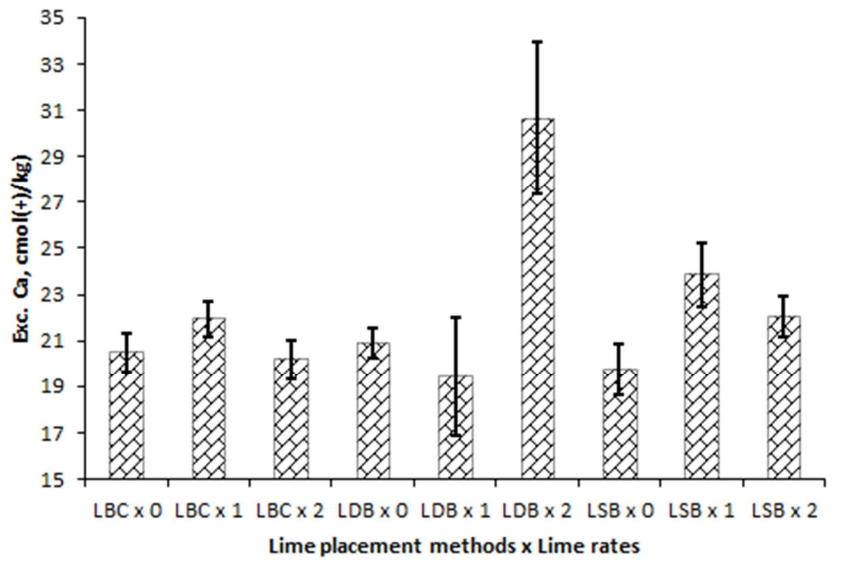

Figure 10. Effects of LPM $x$ LR on exchangeable Ca for $15-30 \mathrm{~cm}$ depth.

\subsection{Effects of Cropping Systems (CS), Lime Placement Methods (LPM) and Lime Rates (LR) on Sugarcane Nutrients Content at Plant Crop and Ratoon One Cycles}

The macronutrient content tested for sugarcane leaves were total nitrogen $(\mathrm{N})$, total phosphorus $(\mathrm{P})$, total potassium $(\mathrm{K})$, total calcium $(\mathrm{Ca})$ and total magnesium $(\mathrm{Mg})$ as shown in Table 9. The micronutrients were total manganese (Mn) and total zinc $(\mathrm{Zn})$ as shown in Table 10.

Cropping systems significantly $(\mathrm{P}=0.05)$ affected sugarcane total $\mathrm{N}$ for ratoon one cycle at the $12^{\text {th }}$ month after ratoon one emergence (MaR) (Table 9). Sugarcane under MC recorded higher total $\mathrm{N}(1.13 \%)$ compared to sugarcane under IC (1.09\%) (Table 11). However, the levels of $\mathrm{N}$ recorded for both $\mathrm{CS}$ were below the critical value for sugarcane, which is $<1.80 \%[31,32]$.

Cropping systems significantly influenced sugarcane total $\mathrm{Ca}(\mathrm{P}=0.04)$ and total $\mathrm{Mn}(\mathrm{P}=0.05)$ for plant crop cycle at the $18^{\text {th }}$ month after planting (Table 9 and 10).. Sugarcane under IC recorded higher total $\mathrm{Ca}(0.44 \%)$ and total $\mathrm{Mn}$ (76.96 ppm) compared to sugarcane under $\mathrm{MC}$ which was $0.38 \%$ and $64.93 \mathrm{ppm}$ for total $\mathrm{Ca}$ and total $\mathrm{Mn}$, respectively. The total $\mathrm{Ca}$ recorded was in the optimum range $(0.2-$ $0.45 \%$ ) (Table 11 and 12 ). Likewise for total Mn was in the optimum range $(20-100 \mathrm{ppm})$. The critical ranges are according to [31] and [32].

Lime placement methods significantly affected the sugarcane total $\mathrm{N}$ for plant crop cycle at $18^{\text {th }}$ month after planting (MAP). Sugarcane under plots that lime was broadcasted (L-BC) showed highest total $\mathrm{N}(0.47 \%)$ compared to those under plots that lime was shallow banded (L-SB) or deep - banded (L-DB), which was $0.41 \%$ and $0.40 \%$, respectively (Table 11 ). However, the levels of total $\mathrm{N}$ were below the critical value $(<1.80 \%)$. Lime placement methods significantly affected the sugarcane total $\mathrm{P}$ for plant crop cycle at $18^{\text {th }}$ MAP (Table 11). Sugarcane under plots that were L-BC recorded the highest $\mathrm{P}(0.08 \%)$ compared sugarcane under L-SB and L-DB, which was $0.06 \%$ and $0.06 \%$, respectively (Table 11 ). 
Table 9. $F$ - test probabilities for the effects of cropping systems (CS), lime placement methods (LPM) and lime rates (LR) on total Nitrogen (N), total Phosphorus $(P)$, total potassium $(K)$ and total calcium $(\mathrm{Ca})$ content in sugarcane leaves at plant crop cycle and ratoon one cycle.

\begin{tabular}{llllllllllllll}
\hline \multicolumn{1}{l}{ F test probabilities } & Total N & \multicolumn{3}{c}{ Total P } & \multicolumn{3}{c}{ Total K } & \multicolumn{3}{c}{ Total Ca } \\
\hline SOV & d.f. & PC & $\begin{array}{l}\text { R1, 9 } \\
\text { MAR }\end{array}$ & $\begin{array}{l}\text { R1, 12 } \\
\text { MAR }\end{array}$ & PC & $\begin{array}{l}\text { R1, 9 } \\
\text { MAR }\end{array}$ & $\begin{array}{l}\text { R1, 12 } \\
\text { MAR }\end{array}$ & PC & $\begin{array}{l}\text { R1, 9 } \\
\text { MAR }\end{array}$ & $\begin{array}{l}\text { R1, 12 } \\
\text { MAR }\end{array}$ & $\begin{array}{l}\text { PC } \\
\text { R1,9 } \\
\text { MAR }\end{array}$ & $\begin{array}{l}\text { R1, 12 } \\
\text { MAR }\end{array}$ \\
\hline CS & 1 & 0.110 & 0.669 & 0.114 & 0.942 & 0.944 & 0.721 & 0.458 & 0.138 & 0.774 & 0.003 & 0.187 & 0.750 \\
LPM & 2 & 0.015 & 0.828 & 0.177 & $<0.001$ & 0.134 & 0.969 & 0.518 & 0.538 & 0.460 & 0.021 & 0.159 & 0.366 \\
LR & 2 & 0.109 & 0.521 & 0.293 & 0.127 & 0.238 & 0.140 & 0.773 & 0.824 & 0.153 & 0.641 & 0.163 & 0.334 \\
CS x LPM & 2 & 0.340 & 0.828 & 0.716 & 0.904 & 0.951 & 0.986 & 0.165 & 0.366 & 0.659 & 0.278 & 0.242 & 0.811 \\
CS x LR & 2 & 0.344 & 0.815 & 0.038 & 0.979 & 0.671 & 0.727 & 0.616 & 0.242 & 0.730 & 0.941 & 0.637 & 0.312 \\
LPM x LR & 4 & 0.144 & 0.669 & 0.461 & 0.058 & 0.169 & 0.508 & 0.795 & 0.279 & 0.196 & 0.525 & 0.601 & 0.276 \\
CS x LPM x LR & 4 & 0.153 & 0.049 & 0.732 & 0.787 & 0.224 & 0.743 & 0.669 & 0.039 & 0.389 & 0.868 & 0.619 & 0.513 \\
\hline
\end{tabular}

Significant effect at $\mathrm{P} \leq 0.05 ; \mathrm{CS}$ - cropping systems; LPM - lime placement methods; LR - lime rates; PC - plant crop cycle; R 1 - ratoon one crop cycle; $\mathrm{MaP}$ - months after planting sugarcane setts; $\mathrm{MaR}$ - months after ratoon one emergence; d.f. - degrees freedom;

Table 10. F - test probabilities for the effects of cropping systems (CS), lime placement methods (LPM) and lime rates (LR) on total Magnesium (Mg), total Manganese (Mn) and total Zinc (Zn) content in sugarcane leaves at plant crop cycle and ratoon one cycle.

\begin{tabular}{lllllllllll}
\hline F test probabilities & \multicolumn{4}{l}{ Total magnesium } & \multicolumn{3}{l}{ Total manganese } & \multicolumn{3}{c}{ Total zinc } \\
\hline SOV & d.f. & PC & $\begin{array}{l}\text { R1, 9 } \\
\text { MAR }\end{array}$ & $\begin{array}{l}\text { R1, 12 } \\
\text { MAR }\end{array}$ & PC & $\begin{array}{l}\text { R1, 9 } \\
\text { MAR }\end{array}$ & $\begin{array}{l}\text { R1, 12 } \\
\text { MAR }\end{array}$ & PC & $\begin{array}{l}\text { R1,9 } \\
\text { MAR }\end{array}$ & $\begin{array}{l}\text { R1, 12 } \\
\text { MAR }\end{array}$ \\
\hline CS & 1 & 0.077 & 0.419 & 0.336 & 0.004 & 0.419 & 0.479 & 0.600 & 0.896 & 0.941 \\
LPM & 2 & 0.714 & 0.739 & 0.967 & 0.465 & 0.626 & 0.106 & 0.719 & 0.063 & 0.395 \\
LR & 2 & 0.561 & 0.225 & 0.728 & 0.183 & 0.317 & 0.666 & 0.378 & 0.097 & 0.332 \\
CS x LPM & 2 & 0.442 & 0.309 & 0.543 & 0.413 & 0.904 & 0.546 & 0.335 & 0.344 & 0.263 \\
CS x LR & 2 & 0.624 & 0.876 & 0.559 & 0.918 & 0.696 & 0.003 & 0.927 & 0.917 & 0.965 \\
LPM x LR & 4 & 0.626 & 0.449 & 0.455 & 0.845 & 0.647 & 0.964 & 0.792 & 0.692 & 0.078 \\
CS x LPM x LR & 4 & 0.413 & 0.154 & 0.085 & 0.127 & 0.817 & 0.204 & 0.129 & 0.807 & 0.349 \\
\hline
\end{tabular}

Significant effect at P $\leq 0.05$; CS - cropping systems; LPM - lime placement methods; LR - lime rates; PC - plant crop cycle; R 1 - ratoon one crop cycle; $\mathrm{MaP}$ - months after planting sugarcane setts; $\mathrm{MaR}$ - months after ratoon one emergence; d.f. - degrees freedom;

Table 11. Effects of cropping systems, lime placement methods and rates on sugarcane uptake of nitrogen, phosphorus and potassium at plant crop and ratoon one cycles.

\begin{tabular}{|c|c|c|c|c|c|c|c|c|c|c|}
\hline \multirow[b]{2}{*}{ Factors } & \multirow[b]{2}{*}{ Levels / Stage } & \multicolumn{3}{|c|}{ Total nitrogen $(\% \mathrm{~N})$} & \multicolumn{3}{|c|}{ Total phosphorus (\% P) } & \multicolumn{3}{|c|}{ Total potassium $(\% \mathrm{~K})$} \\
\hline & & $\begin{array}{l}\text { PC - 18th } \\
\text { MaP }\end{array}$ & $\begin{array}{l}\text { R 1-9th } \\
\text { MaR }\end{array}$ & $\begin{array}{l}\text { R 1-12th } \\
\text { MaR }\end{array}$ & $\begin{array}{l}\text { PC - 18th } \\
\text { MaP }\end{array}$ & $\begin{array}{l}\text { R 1-9th } \\
\text { MaR }\end{array}$ & $\begin{array}{l}\text { R 1-12th } \\
\text { MaR }\end{array}$ & $\begin{array}{l}\text { PC-18th } \\
\text { MaP }\end{array}$ & $\begin{array}{l}\text { R 1 - 9th } \\
\text { MaR }\end{array}$ & $\begin{array}{l}\text { R 1-12th } \\
\text { MaR }\end{array}$ \\
\hline \multirow{4}{*}{$\begin{array}{l}\text { Cropping } \\
\text { systems (CS) }\end{array}$} & $\mathrm{MC}$ & 0.42 & 1.17 & $1.13 \mathrm{a}$ & 0.07 & 0.13 & 0.13 & 0.58 & 0.62 & 0.61 \\
\hline & IC & 0.45 & 1.16 & $1.09 \mathrm{~b}$ & 0.07 & 0.13 & 0.13 & 0.63 & 0.56 & 0.60 \\
\hline & $\operatorname{LSD}(\mathrm{P} \leq 0.05)$ & NS & NS & 0.04 & NS & NS & NS & NS & NS & NS \\
\hline & L-BC & $0.47 \mathrm{a}$ & 1.17 & 1.08 & $0.08 \mathrm{a}$ & 0.13 & 0.13 & 0.55 & 0.57 & 0.62 \\
\hline \multirow{3}{*}{$\begin{array}{l}\text { Lime placement } \\
\text { Methods (LPM) }\end{array}$} & L-DB & $0.40 \mathrm{~b}$ & 1.18 & 1.12 & $0.06 \mathrm{~b}$ & 0.13 & 0.13 & 0.61 & 0.62 & 0.63 \\
\hline & L-SB & $0.41 b$ & 1.16 & 1.13 & $0.06 \mathrm{~b}$ & 0.14 & 0.13 & 0.66 & 0.58 & 0.58 \\
\hline & $\operatorname{LSD}(P \leq 0.05)$ & 0.04 & NS & NS & 0.02 & NS & NS & NS & NS & NS \\
\hline \multirow{8}{*}{$\begin{array}{l}\text { Lime rates (LR) } \\
-\mathrm{t} \mathrm{ha}^{-1}\end{array}$} & 0 & 0.43 & 1.17 & 1.12 & 0.06 & 0.14 & 0.12 & 0.58 & 0.59 & 0.61 \\
\hline & 1 & 0.46 & 1.15 & 1.13 & 0.07 & 0.13 & 0.14 & 0.64 & 0.57 & 0.56 \\
\hline & 2 & 0.41 & 1.19 & 1.08 & 0.06 & 0.13 & 0.13 & 0.59 & 0.60 & 0.65 \\
\hline & $\operatorname{LSD}(P \leq 0.05)$ & NS & NS & NS & NS & NS & NS & NS & NS & NS \\
\hline & CS x LR & NS & NS & NS & NS & NS & NS & NS & NS & NS \\
\hline & LPM x LR & NS & NS & NS & 0.04 & NS & NS & NS & NS & NS \\
\hline & CS $x$ LPM $x$ LR) & NS & NS & NS & NS & NS & NS & NS & 0.04 & NS \\
\hline & CV (\%) & 16.1 & 8.3 & 8.3 & 25.9 & 11.8 & 19.3 & 41.3 & 22.8 & 20.2 \\
\hline
\end{tabular}

Means in the same column followed by the same letter (s) are not significantly different at 0.05 level. Key: NS - not significant at $(\mathrm{P}=0.05)$; CV - coefficient of variation; MC - Sugarcane monoculture; IC - Intercropped sugarcane; L-BC - lime broadcasted; L-DB - lime deep banded; L-SB - lime shallow banded. $\mathrm{PC}$ - plant crop cycle; R 1 - ratoon one crop cycle; $\mathrm{MaP}$ - months after planting sugarcane setts; MaR - months after ratoon one emergence 
Table 12. Effects of cropping systems (CS), lime placement methods (LPM) and rates (LR) on sugarcane uptake of calcium, magnesium, manganese and zinc at plant crop and ratoon one cycles.

\begin{tabular}{|c|c|c|c|c|c|c|c|c|c|c|c|c|c|}
\hline \multirow[b]{2}{*}{ Factors } & \multirow[b]{2}{*}{ Levels } & \multicolumn{3}{|c|}{ Total Calcium (\% Ca) } & \multicolumn{3}{|c|}{ Total magnesium (\% Mg) } & \multicolumn{3}{|c|}{ Total manganese (ppm, Mn) } & \multicolumn{3}{|c|}{ Total zinc (ppm Zn) } \\
\hline & & PC - 18 & R 1 - 9 & R 1 - 12 & PC - 18 & R 1 - 9 & R 1 - 12 & PC - 18 & R 1 - 9 & R 1 - 12 & PC -18 & R 1 - 9 & R 1 - 12 \\
\hline \multirow{3}{*}{ CS } & $\mathrm{MC}$ & 0.38 & 0.39 & 0.41 & 0.07 & 0.13 & 0.17 & $64.93 b$ & 44.30 & 50.56 & 3.22 & 16.08 & 13.17 \\
\hline & IC & 0.44 & 0.43 & 0.42 & 0.08 & 0.15 & 0.15 & $76.96 \mathrm{a}$ & 47.02 & 48.55 & 3.67 & 15.86 & 12.94 \\
\hline & $\operatorname{LSD}(P \leq 0.05)$ & 0.05 & NS & NS & NS & NS & NS & 11.43 & NS & NS & NS & NS & NS \\
\hline \multirow{4}{*}{ LPM } & L-BC & 0.37 & 0.44 & 0.43 & 0.07 & 0.13 & 0.17 & 67.44 & 45.13 & 52.09 & 3.50 & $13.03 \mathrm{~b}$ & 10.22 \\
\hline & L-DB & 0.42 & 0.37 & 0.45 & 0.07 & 0.15 & 0.16 & 72.72 & 47.86 & 51.34 & 3.00 & $16.95 \mathrm{a}$ & 13.61 \\
\hline & L-SB & 0.44 & 0.42 & 0.37 & 0.07 & 0.14 & 0.16 & 72.67 & 43.99 & 45.23 & 3.83 & $17.93 \mathrm{a}$ & 15.34 \\
\hline & $\operatorname{LSD}(P \leq 0.05)$ & 0.03 & NS & NS & NS & NS & NS & NS & NS & NS & NS & 1.53 & NS \\
\hline \multirow{5}{*}{ LR } & $0 \mathrm{t} \mathrm{ha}^{-1}$ & 0.40 & 0.40 & 0.46 & 0.07 & 0.12 & 0.16 & 76.22 & 49.16 & 51.29 & 3.11 & 18.14 & 11.71 \\
\hline & $1 \mathrm{tha}^{-1}$ & 0.42 & 0.38 & 0.39 & 0.07 & 0.16 & 0.18 & 68.17 & 43.04 & 49.12 & 2.94 & 16.32 & 11.13 \\
\hline & $2 \mathrm{t} \mathrm{ha}^{-1}$ & 0.40 & 0.45 & 0.39 & 0.07 & 0.14 & 0.16 & 68.44 & 44.78 & 48.25 & 4.28 & 13.45 & 16.32 \\
\hline & $\operatorname{LSD}(P \leq 0.05)$ & NS & NS & NS & NS & NS & NS & NS & NS & NS & NS & NS & NS \\
\hline & CV (\%) & 19.3 & 28.8 & 39.6 & 20.8 & 43.3 & 63.9 & 20.6 & 29.4 & 20.7 & 90.7 & 43.8 & 82.1 \\
\hline
\end{tabular}

Means in the same column followed by the same letter (s) are not significantly different at 0.05 level of significance. Key: NS - not significant at ( $\mathrm{P}=0.05$ ); $\mathrm{CV}$ - coefficient of variation; MC - Sugarcane monoculture; IC - Intercropped sugarcane; L-BC - lime broadcasted; L-DB - lime deep banded; L-SB - lime shallow banded.

Lime placement methods significantly affected the sugarcane total Ca for plant crop cycle at $18^{\text {th }}$ MAP (Table 9 and 11). Sugarcane under plots that were L-SB recorded the highest $\mathrm{Ca}(0.44 \%)$ compared to sugarcane under L-BC and L-BD, which was $0.37 \%$ and $0.42 \%$, respectively. The levels of total $\mathrm{Ca}$ was at optimum range $(0.20-0.45 \% \mathrm{Ca})$. Lime placement methods significantly affected the sugarcane total $\mathrm{Zn}$ for ratoon one crop cycle at $9^{\text {th }}$ month after ratoon emergence (Table 10 and 12). Sugarcane under plots that were L-SB recorded the highest $\mathrm{Zn}$ (17.93 ppm) compared to sugarcane under L-BD and also under L-BC which was $16.95 \mathrm{ppm}$ and $13.03 \mathrm{ppm}$, respectively. In terms of levels, sugarcane total $\mathrm{Zn}$ at $17.93 \%$ was within optimum range (17 - $32 \mathrm{ppm}$ ), those at $16.95 \%$ was between critical value (>15 ppm) and optimum range, those at $13.03 \mathrm{ppm}$ were below the critical $\mathrm{Zn}$ value $(<15 \%)$ according to [31] and [32].

There was no significant effect of lime rates on the nutrients content in sugarcane leaves during the plant crop cycle and also ratoon one cycle.

The leaf nutrient status was assessed based on the treatments, crop cycle and age at time of leaf sampling. Time of leaf sampling especially for fertilizer recommendations should be carried out during the actively growing stage of sugarcane, hereby referred to the grand growth stage [31] and [32].

The four sugarcane growth stages are germination and establishment phase; tillering phase; grand growth phase and ripening and maturation phase $[33 ; 34]$. Germination denotes activation and subsequent sprouting of the vegetative bud from the planted sugarcane setts (sugarcane vegetative planting material). Tillering involves physiological process of repeated under ground branching from compact nodal joints of the primary shoot. Grand growth involves actual sugarcane formation and elongation and thus yield build up.
Finally, Ripening and maturation phase entails sugar synthesis and rapid accumulation of sugar takes place while the vegetative growth is reduced.

Nitrogen is one of the main building blocks of proteins. Nitrogen is responsible for growth and expansion of green leaves and is essential for photosynthesis and sugar production [31]. The sugarcane leaf total $\mathrm{N}$ across the treatments, crop cycle and age was very low regarded as below the critical $\mathrm{N}$ level $(<1.80 \%)$. At plant crop cycle and $18^{\text {th }}$ month, the sugarcane leaf $\mathrm{N}$ content ranged from mean of 0.41 to $0.47 \%$ (Table 11 ). However, at ratoon crop cycle at $9^{\text {th }}$ and $12^{\text {th }}$, sugarcane leaf $\mathrm{N}$ range was $(1.15$ to $1.17 \%)$ and (1.08 to $1.13 \%$ ) respectively (Table 2.11 ). It appears the low total $\mathrm{N}$ is attributed to the time the leaves were sampled. [35] stated that sugarcane crop age as one of the factors influencing leaf analysis and nutrient content. [35] reported that leaf $\mathrm{N}$ decreased markedly from a mean of $2.70 \%$ at $1^{\text {st }}$ month to $1.85 \%$ in the $4^{\text {th }}$ month and further decreased to $1.67 \%$ in the $9^{\text {th }}$ month.

Phosphorus is essential for the formation of a strong and vigorous root system and plays a role in photosynthesis and many other biochemical processes such as cell division and cell growth $[31,36]$. The sugarcane leaf $\mathrm{P}$ content was very low regarded as below the critical leaf P level $(<0.18 \%)$. At plant crop cycle and $18^{\text {th }}$ month, the sugarcane leaf $\mathrm{P}$ content ranged from mean of 0.02 to $0.08 \%$ (Table 11). The ratoon crop cycle at $9^{\text {th }}$ and $12^{\text {th }}$, sugarcane leaf $\mathrm{P}$ range was $(0.13$ to $0.14 \%$ ) and $(0.12$ to $0.13 \%)$ respectively (Table 11$)$.

Potassium is involved in chlorophyll development, helps the plant use other nutrients and water more efficiently and controls the movement of sugars in the plant. The sugarcane leaf $\mathrm{K}$ content was very low regarded as below the critical leaf $\mathrm{K}$ level $(<1.11 \%)$. At plant crop cycle and $18^{\text {th }}$ month, the sugarcane leaf $\mathrm{P}$ content ranged from mean of 0.55 to 
$0.64 \%$ (Table 11). The ratoon crop cycle at $9^{\text {th }}$ and $12^{\text {th }}$, sugarcane leaf $\mathrm{K}$ range was $(0.56$ to $0.62 \%)$ and (0.56 to $0.65 \%$ ) respectively (Table 11 ).

Calcium is essential for the growth and development of the spindle, leaves and roots. Calcium comprises part of the cell walls, thus strengthening the plant. The sugarcane leaf $\mathrm{Ca}$ content was adequate regarded as above the critical leaf Ca level $(>0.2 \%)$. At plant crop cycle and $18^{\text {th }}$ month, the sugarcane leaf $\mathrm{Ca}$ content ranged from mean of 0.37 to $0.44 \%$ (Table 12). The ratoon crop cycle at $9^{\text {th }}$ and $12^{\text {th }}$, sugarcane leaf $\mathrm{Ca}$ range was $(0.37$ to $0.45 \%)$ and $(0.37$ to $0.46 \%$ ) respectively (Table 12 ).

Magnesium is an essential constituent of chlorophyll where photosynthesis takes place to underpin sugar production and other growth processes [36]. At plant crop cycle aged $18^{\text {th }}$ month, the sugarcane leaf Mg content was very low regarded as below the critical leaf $\operatorname{Mg}(<1.13 \%)$. However, at ratoon one crop cycle aged $9^{\text {th }}$ and $12^{\text {th }}$ month, $\mathrm{Mg}$ content was adequate regarded as above $1.13 \% \mathrm{Mg}$ critical level. The range of leaf $\mathrm{Mg}$ content for ratoon was 0.12 to $0.16 \%$ while for plant crop cycle was 0.07 to $0.08 \%$.

Manganese is involved in photosynthesis, chlorophyll production, and the formation of organic compounds, especially enzyme systems $[31,36]$. The sugarcane leaf $\mathrm{Mn}$ content was adequate regarded as above the critical leaf $\mathrm{Mn}$ level $(>15 \mathrm{ppm})$. At plant crop cycle and $18^{\text {th }}$ month, the sugarcane leaf Mn content ranged from mean of 64 to 72 ppm (Table 12). The ratoon crop cycle at $9^{\text {th }}$ and $12^{\text {th }}$, sugarcane leaf $\mathrm{Mn}$ range was (43 to $49 \mathrm{ppm}$ ) and (48 to 52 ppm) respectively (Table 12 ).

Zinc is involved in chlorophyll formation, the regulation of plant growth and development, and the efficient use of water $[31,36]$. At plant crop cycle aged $18^{\text {th }}$ month, the sugarcane leaf $\mathrm{Zn}$ content was very low regarded as below the critical leaf $\mathrm{Mg}(<10 \mathrm{ppm})$. However, at ratoon one crop cycle aged $9^{\text {th }}$ and $12^{\text {th }}$ month, $\mathrm{Mg}$ content was adequate regarded as above $10 \mathrm{ppm} \mathrm{Zn}$ critical level. The range of leaf $\mathrm{Zn}$ content for ratoon was 3.00 to $4.28 \mathrm{ppm}$ while for plant crop cycle was 11.30 to $17.93 \mathrm{ppm}$.

\subsection{Effects of Interactions of the Main Factors on Nutrient Content of Sugarcane Leaves}

Influence of the interactions of the main factors on nutrient content of sugarcane during plant crop and ratoon one cycle is given in Table 9 and 10. There was significant interaction $(\mathrm{P}=0.01)$ between $\mathrm{CS}$ and $\mathrm{LR}$ on total $\mathrm{Mn}$ in sugarcane leaves during ratoon one cycle at $12^{\text {th }}$ month after ratoon one emergence (Table 10 and Figure 11). Under MC, total $\mathrm{Mn}$ in leaves increased with increase in lime rate. While under IC, total $\mathrm{Mn}$ decreased with increase in LR (Figure 11). There was significant interaction $(P=0.038)$ between $\mathrm{CS}$ and $\mathrm{LR}$ on total $\mathrm{N}$ in sugarcane leaves during ratoon one cycle at $12^{\text {th }}$ month after ratoon one emergence (Table 9,10 and Figure 12). Under MC, total $\mathrm{N}$ in leaves was high when LR used was $1 \mathrm{t} \mathrm{ha}^{-1}$. While under IC, total Nin sugarcane leaves decreased with increase in LR (Figure 12).

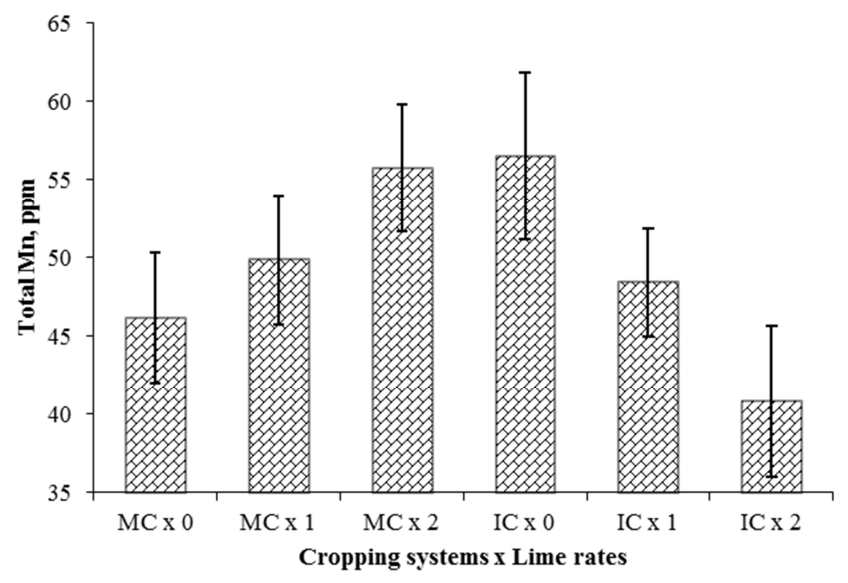

Figure 11. Effects of CS $x$ LR on Mn content in sugarcane leaves.

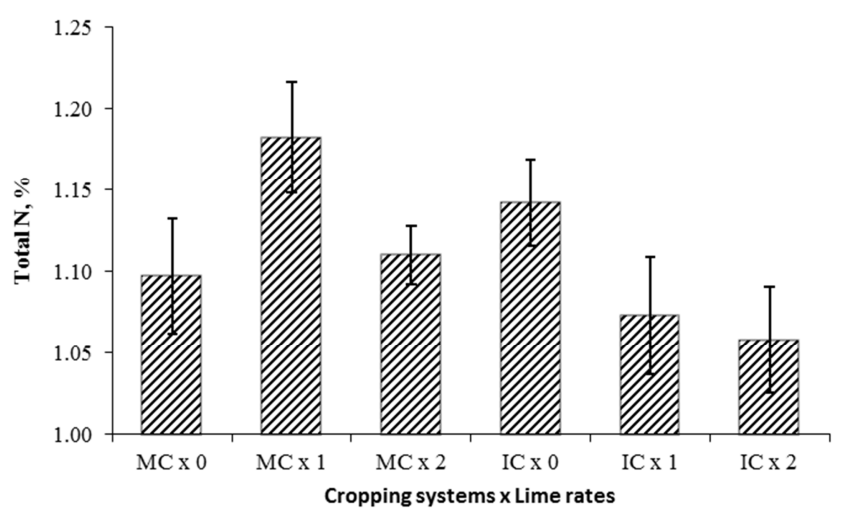

Figure 12. Effects of CS $x$ LR on total $N$ in sugarcane leaves.

\section{Conclusions}

Increased lime rate has been found to ameliorate soil acidity, as evidenced by increased soil $\mathrm{pH}$ from 6.1 to 6.4 (soil $\mathrm{pH}$ in water) or from 4.9 to 5.2 (soil $\mathrm{pH}$ in $\mathrm{KCl}$ ). Lime rate 2 tons ha ${ }^{1}$ was the best to ameliorate soil acidity. Also, increased lime rate led to decreased levels of extractable manganese, iron, and copper, hence confirms the inverse relationship between soil $\mathrm{pH}$ and these micronutrients. Therefore, liming has the potential to reduce toxicity caused by high levels of the micronutrients. Lime placement methods seemed to affect soil properties although variedly. Lime deep banded (L-DB) increased soil $\mathrm{pH}$ and available phosphorus for sub depth 15 $30 \mathrm{~cm}$. This shows that, sub soil acidity is best limed when lime is deep banded as a lime placement method is employed. Intercropped sugarcane and soybeans (IC) led to increased acidity and also soil organic carbon (SOC). The increased acidity is a result of the reaction during decomposition of soil organic carbon / soil organic matter generated from sugarcane and soybean residues. Intercropped sugarcane and soybeans increased Calcium and Manganese content in sugarcane leaves. This increase is attributed to decomposition of soybean residues which then produced calcium. Lime broadcasted (L$\mathrm{BC}$ ) caused high $\mathrm{N}$ and $\mathrm{P}$ content in sugarcane leaves; however the levels were below the critical values. Lime shallow banded resulted in increased $\mathrm{Ca}$ and $\mathrm{Zn}$ in sugarcane leaves to optimum levels. In view of the findings, lime rate 2 
tons $\mathrm{ha}^{-1}$ is recommended for use to ameliorate soil acidity for acidified Cambisols soils of Kibos, Kisumu County, Kenya. Also, lime placement methods should take into consideration the soil $\mathrm{pH}$ stratification with depth. Lime banded should only be employed when sub soil acidity is identified. Lime broadcasted, still remains the preferred lime placement method to ameliorate soil $\mathrm{pH}$ within plough depth $0-15 \mathrm{~cm}$ when acidity is identified.

\section{Acknowledgements}

We thank Alliance for Green Revolution in Africa (AGRA) through AGRA - Soil Health Training Programme for funding the study as part of doctoral study at Sokoine University of Agriculture, Morogoro, Tanzania. Also Kenya Agricultural and Livestock Research Organization - Sugar Research Institute (formerly KESREF) is appreciated for providing additional funds. The field and laboratory staff of KALRO - SRI assisted during experiment management. Finally, we thank the laboratory staff of soil science laboratories of SUA, Morogoro, Tanzania who also assisted in laboratory analysis.

\section{References}

[1] Okalebo, J. R., Othieno, C. O., Nekesa, A. O., NdunguMagiroi, K. W. and Kifuko-Koech, M. N. (2009). Potential for agricultural lime on improved soil health and agricultural production in Kenya. African Crop Science Conference Proceedings 9: 339-341.

[2] Kamprath, E. J. (1984). Crop response to lime on soils in the tropics. In: Soil acidity and liming, $2^{\text {nd }}$ ed. (Edited by Adams, F.). Agronomy 12, American Society of Agronomy 349-368 pp.

[3] Kanyanjua, S. M., Ireri, L., Wambua, S. and Nandwa, S. M. (2002). Acidic Soils in Kenya: Constraints and Remedial Options. KARI Technical Note No. 11. KARI, Nairobi. 24 pp.

[4] Bolan, N. S., Adriano, D. C. and Curtin, D. (2003). Soil acidification and liming interactions with nutrient and heavy metal transformation and bioavailability. Advances in Agronomy 78: 215-272.

[5] Sumner, M. E., Fey, M. V. and Noble, A. D. (1991). Nutrient status and toxicity problems in acid soils. In: Soil acidity. (Edited by Ulrich, B and Sumner, M. E.), Springer-Verlag, Berlin. 149-182 pp.

[6] Brady, N. C. and Weil, R. R. (2008). The Nature and Properties of Soils, $12^{\text {th }}$ edition. Prentice-Hall, Inc., Upper Saddle River, NJ, USA. 881 pp.

[7] Voss, R. (1998). Micronutrients. Department of Agronomy, Iowa State University, USA. [http://www.agr onext.iastate.edu/soilfertility/I nfo/Micronutrients _VossArticle.pdf] site visited on 20/10/2015.

[8] McCauley, A. (2009). Soil pH and organic matter. Nutrient Management Module No. 8, Montana State University Extension. USA. [http://landreso urces.montana.edu/nm/documents/NM8.pdf] sited visited on 20/10/2015.
[9] AGRA (2009). AGRA: Early Accomplishments, Foundations for Growth. Alliance for Green Revolution in Africa, Nairobi. [http://www. agraalliance.org/ early accomplishments] site visited on 3/01/2011.

[10] Haynes, R. J. and Ludeke, T. E. (1981). Effect of lime and phosphorus application on concentration of available nutrients and on $\mathrm{P}, \mathrm{Al}$ and $\mathrm{Mn}$ uptake by two pasture legumes in an acid soil. Plant and Soil 62: 117 - 128.

[11] Bolan, N. S., Hedley, M. J. and White, R. E. (1991). Processes of soil acidification during nitrogen cycling with emphasis on legume based pastures. Plant and Soil 134: 53 - 63.

[12] Amolo, R. A., Sigunga, D. O. and Owuor, P. O. (2011). Spatial variability of some soil properties with sugarcane productivity in western Kenya. In: Proceedings of the $14^{\text {th }}$ Biennial Kenya Society of Sugarcane Technologist 15-16 September, Masinde Muliro University, Kakamega, Kenya. 12-32 pp.

[13] Chianu, J. N., Vanlauwe, B., Mahasi, J. M., Katungi, E., Akech, C., Mairura, F. S., Chianu, J. N. and Sanginga (2008). Soybean situation and outlook analysis: The case of Kenya. [www.icrisat.org/situation-outlook-sbean-kenya.pdf] site visited on 10/09/2014.

[14] FAO (2006). World Reference Base for Soil Resources 2006: A frame work for international classification, correlation and communication. World Soil Resources Report No: 103. Food and Agriculture Organization of the United nations, Rome. $145 \mathrm{pp}$.

[15] Jaetzold, R., Schmidt, H., Hornetz, B. and Shisanya, C. (2007). Farm Management Handbook of Kenya Vol. IINatural Conditions and Farm Management Information-2 ${ }^{\text {nd }}$ Ed. Part A, West Kenya Subpart Al Western Province. Ministry of Agriculture, Kenya and German Agency for Technical Cooperation (GTZ). 317 pp.

[16] Landon, J. R. (1991). Booker Tropical Soil Manual. A Handbook for Soil Survey and Agricultural Land Evaluation in the Tropics and Subtropics. Longman, New York.

[17] Estefan, G., Sommer, R. and Ryan, J. (2013). Methods of soil, plant and water analysis: A manual for the West Asia and North Africa Region. $3^{\text {rd }}$ Edition. International Centre for Agricultural Research in the Dry Areas. ICARDA, Beirut, Lebanon.

[18] IUSS Working Group WRB (2015). World Refrence Base for Soil Resources 2014, update 2015. International soil classification system for naming soils and creating legends for soil maps. World Soil Resources Reports No. 106. FAO, Rome

[19] MacLean, E. O. (1982). Aluminium In: Method of soil Analysis Part 2. Agronomy Monograph No. 9 (Edited by page, A. L., Miller, R. H. and Keeney, P. R.). American Society of Agronomy Inc. Madison, Wisconsin. 221-223 pp.

[20] Moberg, J. R. (2001). Soil and Plant Analysis Manual. The Royal Veterinary and Agriculture University, Chemistry Department, Copenhagen, Denmark. 133 pp.

[21] Bremner, J. M. and Mulvaney, C. S. (1982). Total nitrogen. In: Methods of soil Analysis Part 2. Agronomy Monograph No. 9 (Edited by Page, A. L., Miller, R. H. and Keeney, P. R.). American Society of Agronomy Inc., Madison, Wisconsin. $149-157 \mathrm{pp}$.

[22] GENSTAT (2011). Introduction to GENSTAT 13 for windows. Lowes Agricultural Trust, Rothamsted Experimental Station, Reading University, United Kingdom. 354 pp. 
[23] Nekesa, A. O. (2007). Effect of Minjingu Phosphate Rock and Agricultural Lime in Relation to Maize, Groundnut and Soybean Yields on Acid Soils of Western Kenya. Thesis for award of M. Phil. Degree at Moi University, Eldoret, Kenya. $110 \mathrm{pp}$.

[24] Osundwa, M. A., Okalebo, J. R., Ngetich, W. K., Ochuodho, J. O., Othieno, C. O., Langat, B. and Omenyo, V. S. (2013). Influence of agricultural lime on soil properties and wheat (Triticum aestivum L.) yield on acidic soils of Uasin Gishu County, Kenya. American Journal of Experimental Agriculture 3 (4): 806-823.

[25] Kisinyo, P. O. (2016). Long term effects of lime and phosphorus application on maize productivity in an acid soil of Uasin Gishu County, Kenya. Journal of Agricultural Research 5 (3): 48-55.

[26] Brown, T. T., Koenig, R. T., Huggins, D. R., Harsh, J. B. and Rossi, R. E. (2008). Lime effects on soil acidity, crop yield and aluminium chemistry in direct-seeded cropping systems. Soil Science Society of America Journal 72: 3: 634-640.

[27] Rosa, C. B. C. J., Marchetti, M. E., Serra, A. P., Rosa, S. M., Ensinas, S. C., Conrad, V. A., Altomar, P. H., Potrich, D. C. and Martinez, M. A. (2015). Short term effects of lime management in soybean no-tillage system implementation in Brazilian Savannah. Australian Journal of Crop Science 9 (3): 232-241.

[28] Uren, N. C. (2001). Types, amounts, and possible functions of compounds released into the rhizosphere by soil - grown plants. In: The Rhizosphere: Biochemistry, and Organic Substances at the Soil-Plant Interface (Edited by Pinton, R., Varanini, Z. and Nannipieri, P.), Marcel Dekker, New York. 22-32 pp.

[29] Patra, B. N., and Mohanty, S. K. (1994). Effect of nutrients and liming on changes in $\mathrm{pH}$, redox potential, and uptake of iron and manganese by wetland rice in iron-toxic soil. Biology and Fertility of Soils 17: 285-288.

[30] Stahl, R. S., and James, B. R. (1991). Zinc sorption by B horizon soils as a function of $\mathrm{pH}$. Soil Science Society of America Journal 55: 1592-1597.

[31] Calcino, D., Kingston, G. and Haysom, M. (2000). Nutrition of the plant. Sugar Research Australia. [www.sugarresearch.com.au/icms.../166943

Chapter_9_Nutrition _ of_the_Plant.pdf] ${ }^{-}$site visited on $16 / 06 / 2015$.

[32] McCray, J. M. and Mylavarapu, R. (2013). Sugarcane nutrient management using leaf analysis. University of Florida Institute of Food and Agricultural Sciences. EDIS document SS-AGR-335. [http://edis.ifas.ufl.edu/ag345.pdf] site visited on $16 / 06 / 2015$.

[33] Meyer, J. and Clowes, M. (2011). Sugarcane and Its Environment. In: Good Management Practices Manual for the Cane Sugar Industry. (Edited by Meyer, J). The International Finance Corporation (IFC). Johannesburg. South Africa. $14-51 \mathrm{pp}$.

[34] Rossler, R. L., Singles, A., Oliver, F. C. and Steyn, J. M. (2013). Growth and yield of a sugarcane plant crop under water stress imposed through deficit drip irrigation. Proceedings of South Africa Sugar Technologist Association 86: $170-183$

[35] Schroeder, B. L. (2000). Assessment of leaf analysis of sugarcane under moisture stress considerations. Ph. D. thesis. University of Pretoria., South Africa. 149 pp.

[36] Meyer J. (2011). Sugarcane Nutrition and Fertilization. In: Good Management Practices Manual for the Cane Sugar Industry. (Edited by Meyer, J). The International Finance Corporation (IFC). Johannesburg. South Africa. 173-226 pp. 